\title{
REVIEW
}

\section{Maternal growth factor regulation of human placental development and fetal growth}

\author{
Karen Forbes and Melissa Westwood \\ School of Biomedicine, Maternal and Fetal Health Research Centre, Manchester Academic Health Sciences Centre, University of Manchester, \\ Manchester M13 9WL, UK \\ (Correspondence should be addressed to M Westwood; Email: melissa.westwood@manchester.ac.uk)
}

\begin{abstract}
Normal development and function of the placenta is critical to achieving a successful pregnancy, as normal fetal growth depends directly on the transfer of nutrients from mother to fetus via this organ. Recently, it has become apparent from both animal and human studies that growth factors within the maternal circulation, for example the IGFs, are important regulators of placental development and function. Although these factors act via distinct receptors to exert their effects, the downstream molecules activated upon ligand/receptor interaction are common to
\end{abstract}

many growth factors. The expression of numerous signaling molecules is altered in the placentas from pregnancies affected by the fetal growth complications, fetal growth restriction, and macrosomia. Thus, targeting these molecules may lead to more effective treatments for complications of pregnancy associated with altered placental development. Here, we review the maternal growth factors required for placental development and discuss their mechanism of action.

Journal of Endocrinology (2010) 207, 1-16

\section{Introduction}

Aberrant fetal growth affects as many as $7 \%$ of babies $\sim 50000$ infants born each year in the UK (Population, Censuses \& Surveys Office 2007). Many infants born with inadequate growth (fetal growth restriction; FGR) die, and others require costly neonatal intensive care, while excessive fetal growth (macrosomia) is associated with increased intrapartum risks to the mother and child. In addition, these conditions have a life-long impact on health including elevated childhood morbidity and mortality and an increased risk of developing cardiovascular disease and diabetes in adulthood (Barker 2006). Currently, there are no treatments for cases of altered fetal growth. It is well established that many fetal growth disorders are rooted in defective placental development, thus in order to make significant progress in this area, a better understanding of the mechanisms regulating placental growth is needed.

\section{Placental development and fetal growth}

In chorionic villi of the human placenta (Fig. 1), cytotrophoblasts are a progenitor stem cell population which continuously proliferate and differentiate into one of two subtypes; extravillous trophoblasts that migrate into the maternal decidualized endometrium and remodel the spiral arteries to optimize the supply of oxygen and nutrients to the placenta and fetus; or syncytiotrophoblast, a multinucleated epithelia which acts both to protect the fetus from the maternal immune response and as a nutrient and gas exchange membrane (Fig. 1; Kingdom et al. 2000). As the growth and thus nutrient demands of the fetus increase with pregnancy progression, the syncytial surface area must also increase to ensure sufficient transfer of nutrients to the fetus. The villous syncytiotrophoblast layer has a short lifespan with terminally differentiated and apoptotic elements shedding continuously into maternal circulation. A process to renew and expand the syncytial layer throughout pregnancy is therefore required. The syncytiotrophoblast layer has no transcriptional activity, and hence during pregnancy, it is maintained by the continual proliferation, differentiation, and fusion of cytotrophoblasts.

Consequently, cytotrophoblast proliferation is important for placental growth, especially during the first trimester, when the tissue grows rapidly. Increased or decreased rates of trophoblast turnover have been associated with different tissue pathologies and are linked to enhanced (macrosomic) or reduced (FGR) fetal growth (Jansson \& Powell 2006). In these conditions, the surface area available for transfer of 


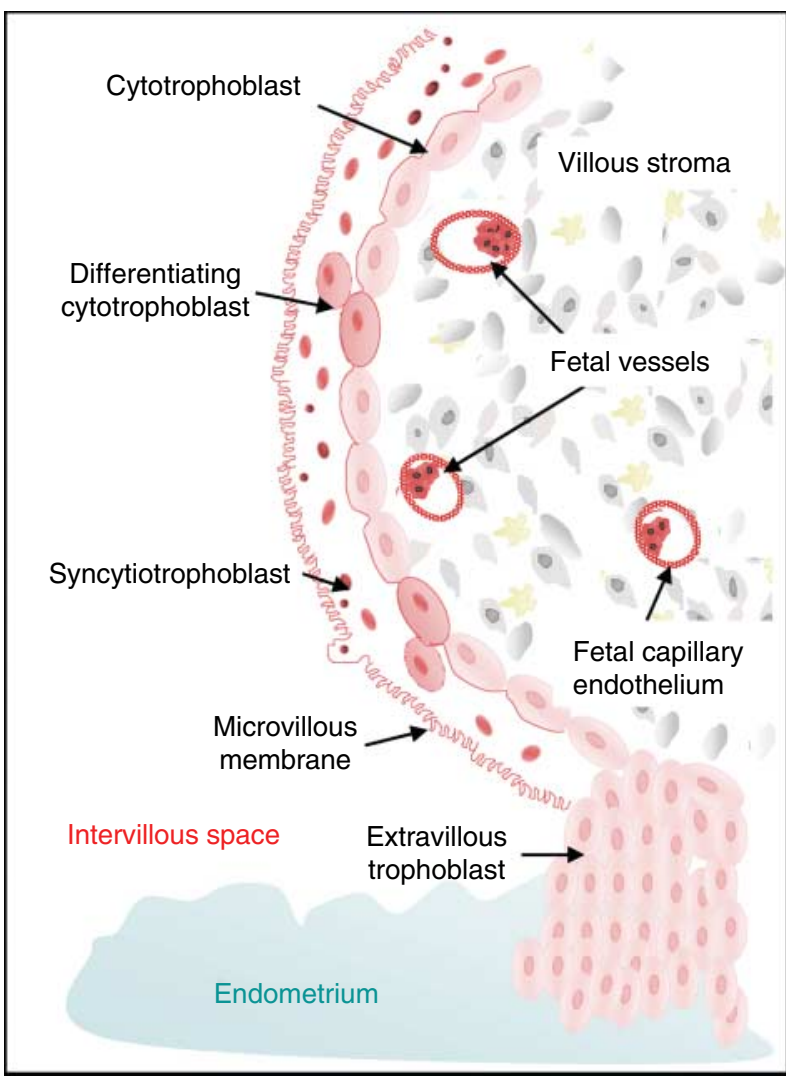

Figure 1 Schematic diagram of the first trimester human placenta. Cytotrophoblasts proliferate and differentiate into one of two subtypes, the invasive extravillous trophoblasts or the terminally differentiated non-proliferative syncytiotrophoblast. The syncytiotrophoblast functions as a protective barrier for the fetus and is the epithelial surface where exchange of nutrients and gases between the maternal and fetal circulations occurs. The villous stroma lies directly below the cytotrophoblast layer and contains numerous different cell types including placental macrophages (Hofbauer cells), fibroblasts, and endothelial cells.

nutrients is altered: an increase in trophoblast proliferation results in enhanced placental nutrient transfer in macrosomia, while the converse occurs in FGR (Jansson \& Powell 2006). Since extravillous trophoblasts invade the maternal circulation and are required to establish an oxygen supply to the fetus, it is unsurprising that alterations in this aspect of trophoblast function are also associated with pregnancy complications such as FGR and pre-eclampsia (Kaufmann et al. 2003); establishing the mechanisms of trophoblast invasion and spiral artery remodeling is the current focus of many research groups (Goldman-Wohl \& Yagel 2002, Lyall 2006, Pijnenborg et al. 2006, Knofler et al. 2008, Harris et al. 2009).

Recently, several studies have suggested that soluble factors in the maternal circulation, including growth factors, can influence placental development and function (Baczyk et al. 2005, Johnstone et al. 2005b, Sferruzzi-Perri et al. 2006, 2007, Moll et al. 2007, Forbes et al. 2008, 2010a,b,c, Hoffmann et al. 2009).
This review will examine the role of such growth factors in the regulation of trophoblast function by briefly discussing their effect on extravillous trophoblast invasion (see the recent review by Knofler (2010) for more detail on this topic), and focussing in detail on the control of villous cytotrophoblast proliferation and function.

\section{Influence of maternal growth factors on fetal growth}

During pregnancy, the levels of growth factors, such as the insulin-like growth factors 1 and 2 (IGF1 and IGF2), epidermal growth factor (EGF), platelet-derived growth factor (PDGF), fibroblast growth factors (FGF)-2 and FGF4, and members of the transforming growth factor (TGF)- $\beta$ superfamily, are increased within the maternal circulation, and these elevated levels are sustained throughout gestation, suggesting that they have important roles in promoting the growth of the developing fetus. The levels of some growth factors such as IGFs and EGF correlate with fetal growth, while others such as TGF $\beta 1$ are not altered (Table 1). However, all of these growth factors exert their effects via intracellular cascades that utilize common signaling molecules; many of which are dysregulated in fetal growth disorders. Therefore, enhancing the growth factor levels alone may not be sufficient to rescue the placental phenotype; instead, it is likely that greater therapeutic benefits may be achieved by targeting growth factor receptors, or indeed the downstream signaling molecules that are responsible for exerting their mitogenic effects. Here, we discuss each of these growth factors and its signaling cascades in the context of their potential role in regulating placental and fetal growth.

\section{The IGF axis}

IGF1 and IGF2 are two small, highly homologous singlechain polypeptides (Le Roith et al. 2001). Although IGF2 can bind to the type-2 IGF/mannose-6-phosphate receptor (IGF2R/M6PR) or the insulin receptor, the classical actions of both IGF1 and 2 are mediated by binding to the type-1 IGF receptor, IGF1R. Ligand access to the receptors is regulated by a family of binding proteins termed IGF-binding proteins (IGFBPs)-1-6. Unsurprisingly, IGFBP levels, particularly IGFBP-1 and IGFBP-3 that are abundant at the maternal-fetal interface, are also correlated with fetal growth (Forbes \& Westwood 2008). Although tissue-specific differences exist, all components of the IGF axis have been shown to mediate growth, differentiation, survival, and metabolism in almost every organ of the body (Jones \& Clemmons 1995), and numerous animal and human studies have highlighted the importance of their actions for fetal growth and development (Tables 1-3).

The involvement of IGFs in regulating fetal growth was first reported in clinical studies demonstrating that birth 
Table 1 Maternal growth factor concentrations in normal pregnancy and in pregnancies associated with fetal growth disorders

Mother

Level $(\mathrm{ng} / \mathrm{ml})$ in circulation during normal and complicated pregnancy

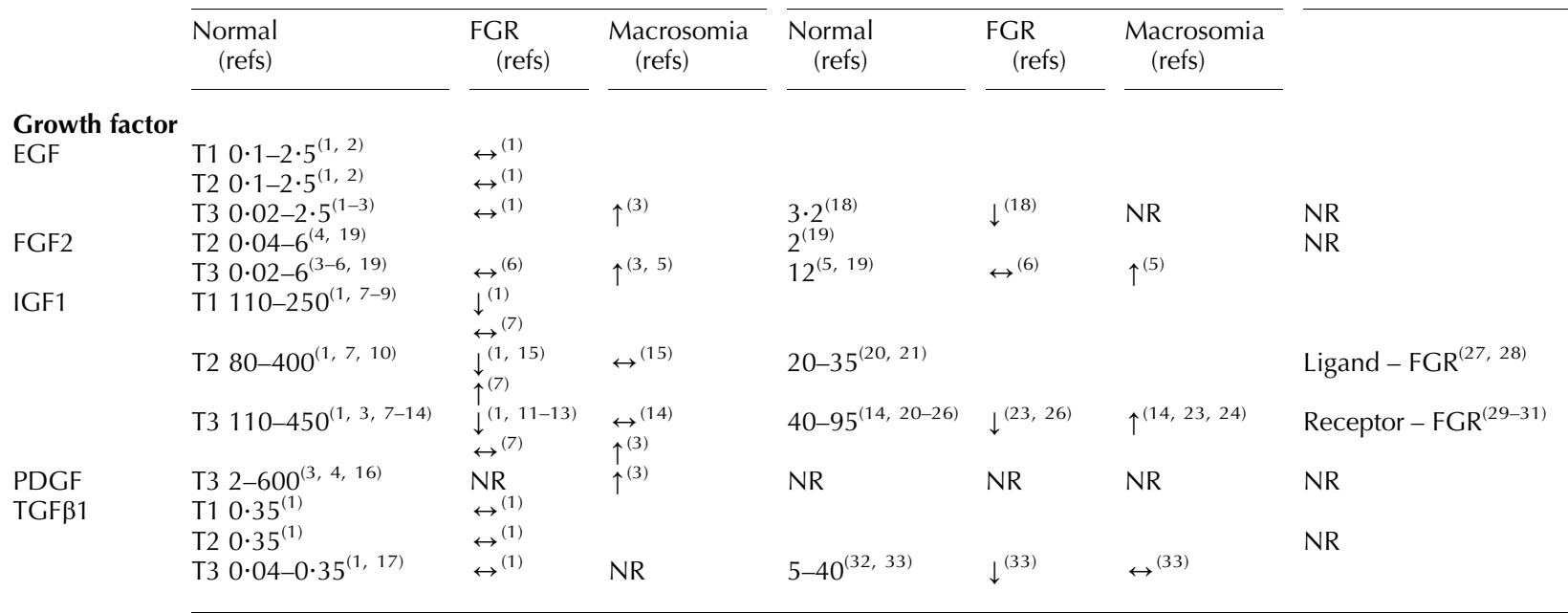

Fetus

Level (ng/ml) in cord blood during normal and complicated pregnancy

Pregnancy pathology associated with ligand or receptor gene defect (refs)

T, trimester; $\uparrow$, increased versus normal pregnancy; $\downarrow$, decreased versus normal pregnancy; $\leftrightarrow$, no change in normal pregnancy; FGR, fetal growth restriction; NR, not reported. 1 - Hernandez-Valencia et al. (2001); 2 - Vuorela et al. (2002); 3 - Grissa et al. (2010); 4 - Chow et al. (2008); 5 - Hill et al. (1995); 6- Wallner et al. (2007); 7 - Bhatia et al. (2002); 8 - Olausson et al. (2010); 9 - Wilson et al. (1982); 10 - Hubinette et al. (2003); 11 - Holmes et al. (1997); 12 - Larsen et al. (1996); 13 - Malamitsi-Puchner et al. (2007); 14 - Wiznitzer et al. (1998); 15 - Mclntyre et al. (2000); 16 - Morita et al. (2001); 17 - Huber et al. (2002); 18 - Shigeta et al. (1992); 19 - Hill et al. (1995); 20 - Langford et al. (1998); 21 - Gohlke et al. (2004); 22 - Reece et al. (1994); 23 - Giudice et al. (1995); 24 - Roth et al. (1996); 25 - Ong et al. (2000); 26 - Verkauskiene et al. (2007); 27 - Woods \& Savage (1996); 28 - Netchine et al. (2009); 29 - Kiess et al. (2005); 30 - Walenkamp et al. (2006); 31 - Wallborn et al. (2010); 32 - Power et al. (2002); 33 - Ostlund et al. (2002).

weight is positively correlated with cord blood IGF1 levels (Osorio et al. 1996, Klauwer et al. 1997), and so levels are low in small-for-gestational-age (SGA) infants and are enhanced in large-for-gestational-age babies (Table 1). Evidence for the importance of IGF2 in this regard comes from the observation that the IGF2 gene is maternally imprinted (Giannoukakis et al. 1993). Relaxation of imprinting leads to BeckwithWiedemann syndrome in which excess IGF2 is associated with fetal overgrowth (Morison et al. 1996, Ward 1997). Subsequent studies using transgenic mice confirmed these clinical observations by demonstrating that mutation of the gene encoding either IGF1 or IGF2 results in offspring that are $\sim 40 \%$ smaller than their wild-type littermates (Efstratiadis 1998; Table 2). More recently, clinical studies have revealed that levels of IGFs within the maternal circulation are also correlated with fetal growth (Table 1) highlighting the potential for maternal IGFs to have an influence on pregnancy outcome (Holmes et al. 1997, Hernandez-Valencia et al. 2001, Grissa et al. 2010).

The mitogenic effects of both IGF1 and 2 are thought to be regulated by IGF1R. Activation of the IGF1R results in autophosphorylation of tyrosine residues in the intracellular $\beta$-subunits and subsequent activation of downstream signaling pathways (Jones \& Clemmons 1995). The significance of IGF1R in mediating IGF effects on fetal growth was first realized by the study demonstrating that igf $1 r$ null mice have a more severe phenotype than either the IGF1 or 2 knockout animals as the birth weight of IGF1R knockout mice is reduced by $\sim 60 \%$ when compared to normal littermates (Efstratiadis 1998; Table 3). More recently, the consequence of IGFR abnormalities in human fetal development has been documented. Severe FGR was reported in two infants with a heterozygous missense mutation in the IGF1R gene (Walenkamp et al. 2006), and heterozygous mutations within the IGF1R kinase domain (Kruis et al. 2010) or extracellular second fibronectin III domain (Wallborn et al. 2010) have been reported in two children. Although these individuals had high circulating levels of IGFs, they were both born SGA which was attributed to IGF resistance arising from reduced IGF1R tyrosine phosphorylation or altered cell surface expression respectively.

The type-2 IGF receptor (IGF2R) does not contain tyrosine kinase activity or an autophosphorylation site, and therefore, classically it was suggested that the primary function of this receptor is to clear IGF2 from the circulation; this is supported by the studies demonstrating that mice lacking the IGF2R/M6PR have raised circulating IGF2 levels and much greater birth weights than their wild-type littermates (Lau et al. 1994, Efstratiadis 1998), and further highlighting the importance of IGF2 in regulating fetal growth (Table 3). 
Table 2 Contribution of growth factors to fetal weight. The effect of alteration in maternal or fetal (gene knockout) growth factor levels on fetal weight

\begin{tabular}{|c|c|c|c|}
\hline & \multicolumn{2}{|l|}{ Mother } & \multirow{2}{*}{$\frac{\text { Fetus }}{\text { Effect of GF gene knockout (refs) }}$} \\
\hline & \multicolumn{2}{|c|}{ Effect of altered GF levels during pregnancy on fetal weight } & \\
\hline & $\uparrow$ Maternal levels (refs) & $\downarrow$ Maternal levels (refs) & \\
\hline $\begin{array}{l}\text { Growth factor } \\
\text { EGF }\end{array}$ & $\begin{array}{l}\text { Rabbit: } 20 \% \uparrow^{(1)} \\
\text { Rat: } \leftrightarrow{ }^{(2)} \\
\text { Sheep: } \leftrightarrow^{(3)}\end{array}$ & Mouse: $15 \% \downarrow^{(11)}$ & No overt phenotype ${ }^{(12)}$ \\
\hline FGF2 & NR & NR & $\begin{array}{l}\text { Neuronal defects; delayed wound } \\
\text { healing }\end{array}$ \\
\hline IGF1 & $\begin{array}{l}\text { Guinea-pig: } 6-17 \% \uparrow^{(4-6)} \\
\text { Mouse: } \uparrow^{(7)} \\
\text { Rat: } \uparrow^{(7)} / \leftrightarrow^{(8,9)} \\
\text { Sheep: } \leftrightarrow^{(10)}\end{array}$ & NR & $\begin{array}{l}\text { Growth deficiency - pups } 60 \% \text { of } \\
\text { normal birth weight }{ }^{(14)}\end{array}$ \\
\hline PDGF & NR & NR & $\begin{array}{l}\text { Renal, cardiovascular, and hemato- } \\
\text { logical abnormalities }\end{array}$ \\
\hline TGF $\beta 1$ & NR & NR & $\begin{array}{l}\text { Variable phenotype (background } \\
\text { dependent): Embryonic lethal } \\
\text { (defective vasculogenesis) }^{(16) /} \\
\text { defective HPG axis }{ }^{(17)}\end{array}$ \\
\hline
\end{tabular}

HPG, hypothalamus-pituitary-gonadal axis; $\uparrow$, increased versus normal pregnancy; $\downarrow$, decreased versus normal pregnancy; $\leftrightarrow$, no change from normal pregnancy; NR, not reported. 1 - Cellini et al. (2004); 2 - Ali et al. (1990); 3 - Gow et al. (1991); 4 - Sferruzzi-Perri et al. (2006); 5 - Sferruzzi-Perri et al. (2006); 6-Sohlstrom et al. (2001); 7 - Gluckman et al.(1992); 8 - Woodall et al. (1999); 9 - Gargosky et al. (1991); 10 - Bloomfield et al. (2002); 11 - Kamei et al. (1999); 12 - Luetteke et al. (1999); 13 - Ortega et al. (1998); 14 - Liu et al. (1993); 15 - Leveen et al. (1994); 16 - Dickson et al. (1995); 17 - Kallapur et al. (1999).

IGF affects fetal growth at least in part through its effect on placental development and function. Undoubtedly, endogenous placental production of IGF2 is key since the placentas of mice with placental-specific knockdown of IGF2 have a significantly reduced diffusional exchange surface area, an enhanced barrier thickness, and a reduced permeability for nutrients (Sibley et al. 2004, Constancia et al. 2005). Placentally derived IGF2 also has a role in promoting trophoblast invasion (Hamilton et al. 1998), reportedly by inhibiting molecules such as IGFBP1 and TIMP3 that are produced by the decidua to constrain trophoblast infiltration of maternal tissues (Irwin et al. 2001). Similarly, IGF1 from the villous mesenchyme provides a paracrine stimulus for extravillous trophoblast migration (Lacey et al. 2002).

However, there is now increasing evidence for the role of maternally derived IGFs in regulating placental development and function (Table 2). In guinea pigs, exogenous supplementation of maternal IGF2 increases the total surface area

Table 3 Effect of growth factor receptor gene knockout in mice

\section{Phenotype of receptor gene knockout}

Receptor
IGF1R
IGF2R
EGFR (ErbB
ErbB2 (H
ErbB3
ErbB4
TGF $\beta R I$
TGF $\beta R I I$
TGF $\beta R V$
FGFR1
FGFR2
FGFR3
FGFR4
PDGFR $\alpha$
PDGFR $\beta$

$45 \%$ of normal fetal weight $135 \%$ of normal fetal growth

No phenotype At least $40-50 \%$ reduction depending on strain

Embryonic lethal prior to E11 (neuronal and cardiovascular defects) Most mice die between E11.5 and E13.5 (neuronal defects); surviving embryos have $10 \%$ reduction in birth weight

Embryonic lethal between E10 and E11 (neuronal and cardiovascular defects)

Embryonic lethal at E10.5 (abnormal vascular development)

Embryonic lethal at E10.5 (abnormal vascular development)

Failure of blastocysts to develop into embryos because of implantation failure

Embryonic lethal (skeletal abnormalities \& global proliferation defects)

Embryonic lethal (skeletal abnormalities global proliferation defects)

$17-93 \%$ of controls (skeletal abnormalities)

Embryonic lethal by E16 (neural tube defects)

Mice die at or shortly before birth (abnormal kidney development and hematological disorders)

\section{References}

Liu et al. (1993)

Ludwig et al. (1996)

Sibilia \& Wagner (1995)

and Dackor et al. (2009)

Lee et al. (1995)

Riethmacher et al. (1997)

Gassmann et al. (1995)

Larsson et al. (2001)

Oshima et al. (1996)

Herz et al. (1992)

Muenke \& Schell (1995)

Muenke \& Schell (1995)

Colvin et al. (1996)

Weinstein et al. (1998)

Soriano (1997)

Soriano (1994) 
of placenta available for nutrient exchange by 39\% (Sferruzzi-Perri et al. 2006). Although IGF1 does not affect the surface area of the placenta in guinea pigs, in vitro studies in both cultured human primary trophoblast cells and the BeWo choriocarcinoma cell line demonstrate that physiological levels of IGF1 enhance amino acid uptake (Karl 1995, Fang et al. 2006). Furthermore, using a first trimester placental explant model which faithfully recapitulates the normal spatial and ontological relationships between the various cells within the placenta, we have recently reported that application of exogenous IGF1 and IGF2 to the syncytial surface (to mimic the maternal circulation) enhances cytotrophoblast proliferation, differentiation, and survival (Forbes et al. 2008).

In the human placenta, the IGF1R is localized to all cell types (Table 4) including the trophoblast, villous endothelium, and the mesenchymal core (Fang et al. 1997, Holmes et al. 1999). Studies of transgenic mice lacking the IGF1R led to the hypothesis that a reduction in the number of placental IGF1R might be a contributing factor in pregnancies complicated by FGR. An immunohistochemical study of placentas from normal and FGR pregnancies found no difference in receptor localization or distribution (Holmes et al. 1999); however, it is possible that in these placentas, there may be resistance to IGF caused by alterations in the downstream signaling molecules. Further studies, however, have demonstrated a significant reduction in IGF1R protein levels in FGR (Laviola et al. 2005), while elevated placental IGF1R expression has been reported in pregnancies complicated by macrosomia (Jiang et al. 2009).

In the placenta, the IGF2R is expressed in the microvillus and plasma membranes of trophoblast (Table 4) but can be proteolytically cleaved, resulting in release of a soluble form of the receptor which, when bound to IGF2, results in degradation of IGF2 and inhibition of its mitogenic actions. Loss of this receptor in mice results in placentomegaly (Wylie et al. 2003) and fetal overgrowth (Lau et al. 1994), and it has been reported in humans that the molar ratio of IGF2 to soluble IGF2R is significantly related to placental development and birth weights (Ong et al. 2000). Until recently, it was thought that the role of IGF2R was to prevent excessive IGF2 effects on the placenta; however, there are now studies to suggest that placental IGF2R is also involved in transducing extracellular signals. Studies in guinea pigs have reported that IGF2R can partially mediate the effects of IGF2 in enhancing placental development and nutrient delivery to promote fetal growth (Sferruzzi-Perri et al. 2008), and both IGF2 and human chorionic gonadotropin increase trophoblast migration via the IGF2R (McKinnon et al. 2001, Zygmunt et al. 2005). The IGF2R does not have any tyrosine kinase activity, thus the mechanism by which the receptor exerts these effects is unclear, although work in other systems has suggested that activation of IGF2R leads to the generation of sphingosine-1-phosphate and consequent signaling through receptors coupled to Gi2 protein (Murayama et al. 1990).

\section{Epidermal growth factor family}

EGF, a polypeptide originally isolated from mouse salivary glands (Cohen 1962), first received attention for its ability to stimulate epithelial growth and differentiation when injected into newborn mice (Scott et al. 1983). Since then, it has become apparent that EGF has mitogenic roles in most organs within the body (Casalini et al. 2004), thus it is unsurprising that EGF also regulates fetal growth and development. In addition to EGF itself, the EGF family comprises 14 different

Table 4 Localization of growth factor receptors within the human placenta

Localization in human placenta

\section{Receptor \\ IGF1R \\ IGF2R \\ ErbB3 \\ ErbB4 \\ TGFßRI \\ TGF $\beta$ RII \\ TGF $\beta R V$ \\ FGFR1 \\ FGFR2 \\ FGFR3 \\ FGFR4 \\ PDGFR}

EGFR (ErbB1)

ErbB2 (HER-2)
Microvillus membrane, syncytiotrophoblast, cytotrophoblast, and villous stroma

Microvillus membrane and syncytiotrophoblast Syncytiotrophoblast and cytotrophoblast

Extravillous trophoblast

Syncytiotrophoblast, cytotrophoblast, and extravillous trophoblast

Syncytiotrophoblast, cytotrophoblast, and extravillous trophoblast

Microvillus membrane, syncytiotrophoblast, and cytotrophoblast

Syncytiotrophoblast

Microvillus membrane

Villous stroma

Villous stroma and cytotrophoblast

Villous stroma

Villous stroma and syncytiotrophoblast

Syncytiotrophoblast and cytotrophoblast
References

Fang et al. (1997), Holmes et al. (1999) and Kita et al. (2003)

Fang et al. (1997)

Maruo \& Mochizuki (1987), Jokhi et al. (1994), Tuncer et al. (2000), Kita et al. (2003) and Tanimura et al. (2004)

Jokhi et al. (1994) and Tanimura et al. (2004)

Tuncer et al. (2000)

Tuncer et al. (2000) and Tanimura et al. (2004)

Xuan et al. (2007) and Forbes et al. (2010c)

Xuan et al. (2007) and Forbes et al. (2010c)

Forbes et al. (2010c)

Anteby et al. (2005)

Anteby et al. (2005) and Baczyk et al. (2005)

Anteby et al. (2005)

Anteby et al. (2005)

Kita et al. (2003) 
ligands (Normanno et al. 2006), including heparin-binding EGF, TGF- $\alpha$, and neuregulin (NRG1). However, the role of these growth factors in fetal growth regulation is unclear.

EGF exerts its effects by binding to its receptor EGFR (also known as the erythroblastic leukemia viral oncogene homolog (ErbB)-1) to stimulate intrinsic tyrosine phosphorylation activity and subsequent activation of pro-mitogenic signaling cascades (Prenzel et al. 2001), while the other family members bind with distinct affinities to one of four ErbB receptors (1-4) to influence cellular events (Harris et al. 2003). Each of the receptors is expressed in the placenta (Tables 4 and 5); ErbB2-4 are expressed both in villous trophoblast and in extravillous trophoblast (Tuncer et al. 2000, Tanimura et al. 2004), but EGFR (ErbB1) is expressed only in villous trophoblast. Alterations in EGFR function are associated with reduced placental and embryonic growth both in mice (Dackor et al. 2009; Tables 2 and 3) and in humans (Fondacci et al. 1994; Tables 1 and 2). Taken together, these studies suggest that signaling via EGFR is important for mediating villous trophoblast function and placental development. This role for EGF/EGFR was confirmed following the discovery that in mice, maternal levels of circulating EGF correlate with fetal growth (Kamei et al. 1999), and that EGFR-deficient mice had significantly smaller placentas and displayed severe FGR (Miettinen et al. 1995). Further evidence for the importance of EGF in regulating placental development and function comes from in vitro studies using human placental cell lines, isolated primary trophoblasts, and explant tissue. EGF increases trophoblast differentiation (Maruo et al. 1987, Barnea et al. 1990, Garcia-Lloret et al. 1996), inhibits trophoblast apoptosis (Johnstone et al. 2005a,b, Moll et al. 2007), and promotes trophoblast proliferation (Li \& Zhuang 1997). Similar models have been used to demonstrate that EGF also stimulates extravillous trophoblast invasion (LaMarca et al. 2008, Han et al. 2010), and the work by Bass et al. (1994) suggests that the stimulus is most likely maternally derived. More recently, intra-amniotic infusion of EGF was reported to normalize fetal weight in a rabbit model of FGR (Cellini et al. 2004) suggesting that targeting the EGF cascade may improve fetal growth.

\section{Transforming growth factor- $\beta$}

The TGF $\beta$ superfamily contains numerous different ligands including TGF $\beta$ s, activins, and bone morphogenic proteins (Jones et al. 2006). Members of the TGF $\beta$ family ligands exert their effects by binding to the type-II TGF $\beta$ receptor (TGF $\beta$ RII) which then dimerizes with the type-I TGF $\beta$ receptor (TGF $\beta R I)$. This dimerization initiates the receptor's serine/threonine kinase activity and induction of divergent signaling cascades that regulate multiple cellular processes including proliferation, migration, and differentiation (Wrighton et al. 2009). Studies in mice have demonstrated that knockout of either TGF $\beta$ RI or TGF $\beta$ RII results in severe growth restriction, and that the animals die in utero (Oshima et al. 1996, Larsson et al. 2001) suggesting that signaling by these receptors is important for regulating fetal growth (Table 3).

Although TGF $\beta 1$ levels are elevated in the maternal circulation during pregnancy (Power et al. 2002), its role in regulating fetal growth is unclear. TGF $\beta 1$ levels are not correlated with fetal growth (Hernandez-Valencia et al. 2001), but a study demonstrating that maternal TGF $\beta 1$ can rescue the embryonic lethal phenotype of TGF $\beta 1$ knockout mice (Letterio et al. 1994) suggests that the growth factor does have an important role during pregnancy (Tables 1 and 2). Indeed, it is well documented that TGF $\beta 1$ functions at the maternalfetal interface to inhibit extravillous trophoblast migration and invasion (Jones et al. 2006, Knofler 2010), seemingly by up-regulating integrin and protease inhibitor expression (Irving \& Lala 1995, Karmakar \& Das 2002); however, its role within the chorionic villous remains controversial.

Table 5 Localization of growth factor receptors in the murine placenta

\section{Localization in murine placenta}

\section{References}

$\begin{array}{ll}\text { Receptor } & \text { Not reported } \\ \text { IGF1R } & \text { Labyrinth and trophoblast giant cells } \\ \text { IGF2R } & \text { Maternal decidua, trophoblast giant cells, and spongiotrophoblast cells } \\ \text { EGFR (ErbB1) } & \text { Not detectable } \\ \text { ErbB2 (HER-2) } & \text { Maternal decidua and trophoblast giant cells } \\ \text { ErbB3 } & \text { Maternal decidua and trophoblast giant cells } \\ \text { ErbB4 } & \text { Trophoblast giant cells, ectoplacental cone and maternal decidua } \\ \text { TGF } \beta \text { RI } & \text { Trophoblast giant cells, ectoplacental cone and maternal decidua } \\ \text { TGF } \beta \text { RII } & \text { Spongiotrophoblast and maternal decidua } \\ \text { TGF } \beta R V & \text { Not reported } \\ \text { FGFR1 } & \text { Not reported } \\ \text { FGFR2 } & \text { Trophoblast giant cells } \\ \text { FGFR3 } & \text { Trophectoderm } \\ \text { FGFR4 } & \text { Labyrinth, spongiotrophoblast and trophoblast giant cells } \\ \text { PDGFR } & \end{array}$

Senior et al. (1990)

Dackor et al. (2007)

Dackor et al. (2007)

Dackor et al. (2007)

Dackor et al. (2007)

Mariano et al. (1998)

Mariano et al. (1998)

Teesalu et al. (1998)

Rappolee et al. (1998)

Rappolee et al. (1998)

Bidwell et al. (1995) 
Studies in both mice and humans have reported that TGF $\beta 1$ promotes cytotrophoblast differentiation into syncytiotrophoblast (or labyrinth in mice; Graham et al. 1992, Selesniemi et al. 2005), while others have suggested that TGF $\beta 1$ inhibits this aspect of trophoblast function (Morrish et al. 1991, Song et al. 1996, Richard et al. 2008). Further controversies come from studies to investigate the mitogenic effects of TGF $\beta$ within the placenta. In a cell line generated from isolated primary trophoblast, TGF $\beta$ inhibits proliferation (Graham et al. 1992), but more recently, we have reported that TGF $\beta 1$ promotes cytotrophoblast proliferation in first trimester explants (Forbes et al. 2010c). Although classically TGF $\beta 1$ was described as a negative regulator of cellular proliferation by activating the TGF $\beta$ RI/II Smad2 signaling cascade, our data are consistent with other reports suggesting that the Smad2 and mitogen-activated protein kinase (MAPK) pathways can interact to promote proliferation in the presence of TGF $\beta$ (Javelaud \& Mauviel 2005, Zhang 2009).

It is likely that the conflicting data reflect differential receptor expression by the various models (Tables 4 and 5), as the level of TGF $\beta$ receptor expression within cells and tissues influences the outcome of TGF treatment (Rojas et al. 2009). Indeed, we have shown that although each of the TGF $\beta$ receptors is expressed in human placenta, the distribution varies, and altering levels of TGF $\beta$ RII using siRNA resulted in altered responsiveness to maternal factors (Forbes et al. $2010 c$ ). It has yet to be established whether placental TGF $\beta R$ expression and signaling responsiveness to ligands are altered in FGR and macrosomia, but drugs to target this level of the cascade could potentially prove to be beneficial.

\section{Fibroblast growth factors}

The FGFs are a family comprising 18 members, FGFs $1-10$ and FGFs 16-23 (Beenken \& Mohammadi 2009). Not all members of the FGF family have the potential to signal, but those that do exert their effects by interacting with four different receptors (FGFR1-4) to activate signal transduction pathways, such as the MAPK cascade, and stimulate mitogenesis, differentiation, and cell migration. FGFs are thus important regulators of multiple developmental processes (Yamaguchi \& Rossant 1995). Although the role of many members of the FGF family in regulating fetal development has yet to be documented, it is apparent that both FGFR1 and FGF2 are important mediators of fetal growth (Tables 1-3). While FGFR1-deficient mice display severe growth restriction in utero (Deng et al. 1994), studies in human pregnancy reveal that maternal and cord serum levels of FGF2 positively correlate with fetal weight (Hill et al. 1995, Grissa et al. 2010). Interestingly, the effect on fetal growth was also accompanied by alterations in placental growth suggesting that FGF2 may exert its effects by influencing placental development. Recent studies support such a role; each of the FGFRs is expressed in the human placenta (Table 4); FGFR1 and FGFR3 are expressed only within the villous stroma, whereas FGFR2 and FGFR 4 are expressed both within the villous stroma and in the trophoblast (Anteby et al. 2005) suggesting that these receptors may mediate the responsiveness of trophoblast to the growth-promoting effects of FGFs. Indeed, studies both in mice and in human placental tissue have demonstrated that FGF4 acts upon FGFR2 within trophoblast stem cells (in mice (Tanaka et al. 1998)) and in the cytotrophoblast (in humans (Baczyk et al. 2005)) to regulate the proliferation and differentiation of these cells within the developing placenta. There are few reports relating to FGF regulation of extravillous trophoblast invasion, though FGF10 appears to be stimulatory (Natanson-Yaron et al. 2007).

\section{Platelet-derived growth factors}

The PDGFs A-C and their receptors PDGFR $\alpha$ and PDGFR $\beta$ have been shown to promote cellular responses such as proliferation, survival, and migration, thus they are important mediators of mammalian development (Hoch \& Soriano 2003). Although reports of the role of PDGF in regulating fetal growth are limited (Tables 1-3), a recent study demonstrates that the maternal serum PDGFB level is enhanced in mothers suffering with gestational diabetes with macrosomic babies (Grissa et al. 2010), and it has been reported that placental levels of PDGFR $\alpha$ are reduced in FGR placentas (Jarvenpaa et al. 2007). In the human placenta (Table 4 ), PDGFR $\alpha / \beta$ is expressed within the syncytiotrophoblast and the villous cytotrophoblast (Kita et al. 2003); this localization together with reduced expression in FGR placentas suggests that signaling via PDGFR $\alpha$ may regulate trophoblast proliferation in the human placenta. At present, there are no direct reports of the role of PDGF/PDGFR signaling in the regulation of human villous, or extravillous, trophoblast function. Studies in mice do, however, support a developmental role for the PDGFR system in the placenta (Ohlsson et al. 1999, Looman et al. 2007). In mice, deletion of the gene encoding PDGFB or PDGFR $\beta$ results in multiple defects in placental development, including decreased trophoblast proliferation (Ohlsson et al. 1999), while an activating mutation in PDGFR $\beta$ induces hyperproliferation in the labyrinth and in the chorionic plate (Looman et al. 2007).

\section{Signaling molecules important for mediating actions of maternal growth factors in the placenta}

Taken together, these studies all suggest that it should be possible to improve placental function by enhancing the response to maternal hormones. For some, but not all, of the growth factors, supplementing maternal levels could be of therapeutic benefit. However, growth factor receptors have a body-wide distribution, and many of their ligands are known 
to promote tumorigenesis, thus maternal systemic administration is unlikely to be without side effects. Instead, other mechanisms to promote growth factor actions within the placenta should be explored; we suggest that methods to specifically target receptors and/or molecules within the placenta are more likely to prove beneficial.

Despite activation of their specific receptors, the downstream effect of the different growth factors is mediated by inducing activation/phosphorylation of common complex signaling cascades such as the phosphoinositide 3-kinase (PI3K) pathway or the MAPK (also termed extracellular signal-related kinase 1/2 (ERK1/2)) pathway (Fig. 2; Vincent \& Feldman 2002). In vivo, the level of phosphorylation within these pathways is regulated by the opposing actions of protein tyrosine kinases (PTKs) and protein tyrosine phosphatases (PTPs). While PTKs catalyze phosphorylation, PTPs are responsible for dephosphorylation. PTKs, PTPs, and their corresponding substrates are integrated within elaborate signaling networks that are essential for regulating many cellular events such as growth, differentiation, metabolism, gene transcription, and survival. These processes are all essential for mediating placental development and function, but until recently the importance of PTKs and PTPs in mediating growth factor action, and consequently normal placental development was unclear.

\section{MAPK pathways}

MAPKs are an evolutionarily conserved group of enzymes that were first identified as mitogen-stimulated kinases in the late 1980s/early 1990s (Pearson et al. 2001) and are now known to be major components of pathways controlling many cellular events. All eukaryotic cells possess multiple MAPK pathways that are activated in response to a wide variety of ligands acting through multiple receptors; these include growth factor receptors such as IGF1R, EGFR, and PDGFR. In mammals, the MAPK cascades can be divided into four distinct groups, MAPK (ERK1/2), c-jun N-terminal kinase (JNK), p38 MAPKs, and the big MAPK, or ERK-5 cascades (Pearson et al. 2001).

Evidence for the involvement of ERK in placental development and subsequent fetal growth comes from studies

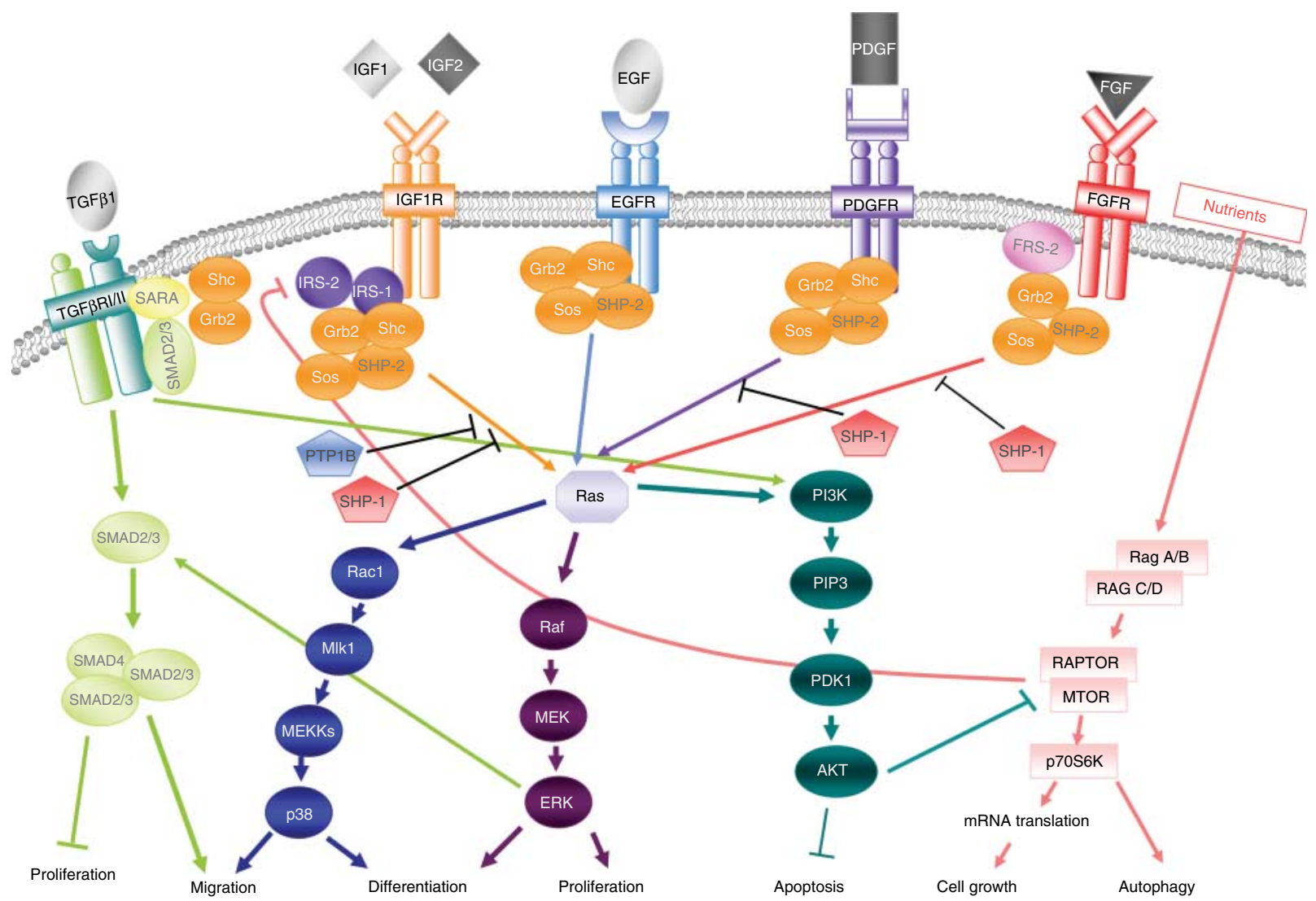

Figure 2 Schematic diagram of growth factor-mediated signaling cascades TGF $\beta 1$, IGF1 and IGF2, EGF, PDGF, and FGF all bind to their cognate receptors thereby inducing receptor autophosphorylation and recruitment of various scaffolding proteins. This results in activation of PI3K and MAPK (ERK) pathways via a sequence of phosphorylation events resulting in transcription of target genes involved in regulating cellular events such as proliferation and survival. 
in mice. Although ERK-1-deficient mice do not exhibit altered growth, mutation within the ERK-2 locus results in failure to form the mature trophoblast leading to embryonic lethality early in mouse development (Saba-El-Leil et al. 2003). Furthermore, ERK-2 knockout mice that have been rescued by the transgenic expression of ERK-2 are much smaller than their wild-type littermates due to abnormal placental development, though when trophoblast function is restored by generating chimeras in which placental trophoblast expression of ERK-2 is normal, embryos grow appropriately, demonstrating the importance of ERK-2 for normal placental development and, consequently, fetal growth (Hatano et al. 2003).

In the human placenta, ERK1/2 are expressed in the villous trophoblast (Kita et al. 2003), and they have been shown to regulate the differentiation of isolated primary cytotrophoblasts into syncytia (Daoud et al. 2005). Many studies demonstrate that activation of the MAPK pathway can be achieved in trophoblast by multiple growth factor receptors and their ligands. EGFR, TGFßR, and IGF2R regulate trophoblast invasion and migration (McKinnon et al. 2001, Qian et al. 2004) via the MAPK pathway, and we have reported that TGF $\beta 1$ (via TGF $\beta$ RI/II)-induced cytotrophoblast proliferation and IGF-induced cytotrophoblast proliferation and differentiation (syncytial regeneration) occur via the MAPK pathway (Forbes et al. 2008, 2010c).

It is generally assumed that ERK1/2 is the major pathway activated by growth factors and other mitogenic stimuli, while JNK and p38 MAPK predominantly respond to stress such as osmotic stress and cytokines (Pearson et al. 2001). While a role for p38 in regulating stress responses has been well documented in the placenta (Renaud et al. 2009), it is now apparent that the p38 MAPK pathway is also an important mediator of growth factor signaling in the placenta. It is required for trophoblast differentiation and fusion in response to different mitogenic factors including serum (Daoud et al. 2005) and EGF (Johnstone et al. 2005b), EGF-induced trophoblast survival (Johnstone et al. 2005a, Humphrey et al. 2008) and extravillous trophoblast motility (LaMarca et al. 2008). Furthermore, p38 $\alpha$ has been shown to be essential for murine placental development (Adams et al. 2000, Mudgett et al. 2000), and in humans phosphorylation (and activation) of p38 is reduced in FGR placentas (Laviola et al. 2005).

\section{PI3K/AKT pathway}

In other tissues, activated growth factors recruit and phosphorylate a number of adaptor molecules and kinases leading to the activation of PI3K/AKT (also known as protein kinase B) and downstream phosphorylation cascades. AKT has been reported to regulate rodent placental development and fetal growth (Chen et al. 2001, Yang et al. 2003), and there is reduced translation of AKT in human FGR placentas (Yung et al. 2008, Scifres \& Nelson 2009). As detailed above, one of the key regulators of placental growth is the IGF axis, and there are many studies demonstrating that the PI3K/AKT pathway mediates IGF responsiveness in the placenta. In a dexamethasone-induced murine model of FGR, reduced levels of IGF2 are accompanied by a significant reduction in levels of phosphorylated AKT (Ain et al. 2005), and in first trimester placental explants, AKT mediates IGF-induced trophoblast survival (Forbes et al. 2008). Further evidence to suggest that the PI3K pathway may be important in mediating IGF signaling events in the placenta comes from studies involving the mechanistic target of rapamycin (MTOR) pathway, which can be activated by phosphorylated AKT to promote cell growth (Levine et al. 2006) or can be regulated by nutrient-sensing signaling pathways (Fig. 2). Studies demonstrating that MTOR acts as a nutrient sensor to promote proliferation of immortalized human trophoblast cells (Wen et al. 2005), and that insulin- and IGF1-mediated amino acid transporter activity is mediated by the MTOR pathway in primary human trophoblast cells (Roos et al. 2009) support this hypothesis and suggest that MTOR may co-ordinate nutrient and growth factor signals to regulate normal placental development.

In addition to regulating events downstream of IGF1R, the PI3K pathway is also an important mediator of other growth factor responses in the placenta. EGF promotes trophoblast proliferation and cell survival by stimulating PI3K/AKT pathway (Johnstone et al. 2005a, Moll et al. 2007), while in placental stromal cells, the PI3K/AKT pathway is required for FGF2 and vascular endothelial growth factor-stimulated endothelial cell proliferation (Wang et al. 2009). It is now emerging that PI3K/AKT may also play additional roles within the placenta by regulating expression of leptin (Gambino et al. 2010), a known mediator of trophoblast proliferation and survival (Magarinos et al. 2007).

\section{Tyrosine phosphatases}

In almost all cells, growth factor-induced activation of the PI3K and MAPK pathways is regulated by PTPs. PTPs were initially thought to be composed of a small number of nonspecific 'house-keeping' enzymes whose only function was to reverse the action of PTKs. However, PTPs are now recognized as a large family of enzymes, which have structural diversity and complexity equivalent to that of the PTKs (Neel \& Tonks 1997). The structural complexity of PTPs enables them to interact with a number of different proteins allowing them to exert both positive and negative effects on signaling pathways; they therefore play crucial roles in a variety of mammalian tissues and cells.

Although the mRNA for a number of PTPs is expressed at high levels within the human placenta (Norris et al. 1997), the function of PTPs at the maternal-fetal interface was relatively unexplored until recently. One PTP, PTP-1B, was first isolated from human placental tissue (Tonks et al. 1988) and has since been reported to be expressed at the protein level in the syncytiotrophoblast (Stenzinger et al. 2008). In other systems, it regulates insulin and IGF signaling (Koren \& Fantus 2007), but its function in the 
placenta is currently unknown. Another phosphatase that appears to be involved in regulating placental development is MAPK phosphatase (MKP)-4. Transgenic mice which have a specific deletion of MKP-4 have abnormal placental development, and all mice die in utero (Christie et al. 2005). MKP-4 functions to regulate the activation of the MAPK pathway, and since this pathway is integral for human placental development and mediating signals from the multiple growth factors, it is possible that this phosphatase may also function to regulate growth factor-induced signaling events in the placenta.

The majority of work examining the role of PTPs within the placenta thus far has focused on the $\mathrm{SH}-2$ domain containing phosphatase, SHP-2. SHP-2 is a ubiquitously expressed intracellular PTP first cloned in 1992 (Adachi et al. 1992). Since then, SHP-2 has been implicated in the regulation of diverse intracellular signaling pathways, including those initiated by ligands such as insulin, IGFs, EGF, PDGF, and FGF (Chong \& Maiese 2007). When SHP-2 is truncated, mice have severe developmental abnormalities and subsequently die at mid gestation (Saxton et al. 1997). It is now established that trophoblast stem cells in these mice fail to proliferate and survive in response to essential growth factors such as FGF4 (Yang et al. 2006) suggesting that the effects on fetal development are caused by the effect of SHP-2 on the placenta (Yang et al. 2006). We have now established that SHP-2 is also important for regulating placental development in humans. SHP-2 is highly abundant within the cytotrophoblast and regulates IGF-induced proliferation by mediating the activation of multiple components of the MAPK and PI3K pathways (Forbes et al. 2009). Interestingly, SHP-2 is absent from the terminally differentiated syncytiotrophoblast. It has been reported that pan-PTP inhibition induces differentiation and fusion in a trophoblast cell line (Vargas et al. 2008), thus a possible explanation for the absence of SHP-2 in the syncytium is that SHP-2 negatively regulates trophoblast differentiation and is therefore reduced prior to differentiation and fusion; however, this remains to be established.

SHP-1 is a structurally similar PTP to SHP-2, but while SHP-2 can have both positive and negative actions, the role of SHP-1 is predominantly as a negative regulator of cellular events (Neel et al. 2003) including those activated by FGF2 (Seo et al. 2008), IGF1 (Tenev et al. 1997), and PDGF (Yu et al. 1998). Mice with an inactivating mutation of SHP-1 have enhanced cellular proliferation (Shultz et al. 1993, Tsui et al. 1993), and it is now emerging that SHP-1 can negatively regulate activation of the MAPK cascade (Zatelli et al. 2005). SHP-1 mRNA is expressed within the placenta (Norris et al. 1997) and is highly abundant both within the cytotrophoblast and within the villous stroma in the first trimester human placenta (Forbes et al. 2010a), thus suggesting a potential role in regulating cytotrophoblast function. Indeed, we now have evidence that SHP-1 inhibits cytotrophoblast proliferation by negatively regulating multiple receptor tyrosine kinases (Forbes et al. 2010b).
Targeting intracellular signaling molecules to improve placental growth

We have discussed the role of maternal growth factors in regulating villous trophoblast turnover, and it is apparent that all of these growth factors have similar roles within the placenta. Although each ligand binds to distinct receptors on the cell surface, each receptor initiates common intracellular signaling cascades through the action of both kinases and phosphatases, and there are studies demonstrating that the expression of these proteins is essential for growth factor responses in the normal human placenta. The placental expression of numerous proteins within these cascades is altered in fetal growth complications. We therefore propose that instead of supplementing maternal growth factor levels, the greatest therapeutic benefits in pregnancies complicated by altered fetal growth will arise by developing mechanisms to specifically manipulate the expression/activation of signaling molecules which are common to multiple growth factor receptors within the placenta.

\section{Declaration of interest}

The authors declare that there is no conflict of interest that could be perceived as prejudicing the impartiality of the review reported.

\section{Funding}

$\mathrm{KF}$ is funded by a University of Manchester Stepping Stones Fellowship and the Maternal and Fetal Health Research Centre is supported by funding from the NIHR Manchester Biomedical Research Centre.

\section{References}

Adachi M, Sekiya M, Miyachi T, Matsuno K, Hinoda Y, Imai K \& Yachi A 1992 Molecular cloning of a novel protein-tyrosine phosphatase SH-PTP3 with sequence similarity to the src-homology region 2 . FEBS Letters 314 335-339. (doi:10.1016/0014-5793(92)81500-L)

Adams RH, Porras A, Alonso G, Jones M, Vintersten K, Panelli S, Valladares A, Perez L, Klein R \& Nebreda AR 2000 Essential role of p38 $\alpha$ MAP kinase in placental but not embryonic cardiovascular development. Molecular Cell 6 109-116. (doi:10.1016/S1097-2765(05)00014-6)

Ain R, Canham LN \& Soares MJ 2005 Dexamethasone-induced intrauterine growth restriction impacts the placental prolactin family, insulin-like growth factor-II and the Akt signaling pathway. Journal of Endocrinology 185 253-263. (doi:10.1677/joe.1.06039)

Ali P, D’Souza SW \& Smart JL 1990 Epidermal growth factor administered in pregnancy has little effect on placental, fetal and postnatal growth and development in rats. Biology of the Neonate 57 318-324. (doi:10.1159/ 000243207)

Anteby EY, Natanson-Yaron S, Hamani Y, Sciaki Y, Goldman-Wohl D, Greenfield C, Ariel I \& Yagel S 2005 Fibroblast growth factor-10 and fibroblast growth factor receptors 1-4: expression and peptide localization in human decidua and placenta. European Journal of Obstetrics, Gynecology, and Reproductive Biology 119 27-35. (doi:10.1016/j.ejogrb.2004.05.014)

Baczyk D, Dunk C, Huppertz B, Maxwell C, Reister F, Giannoulias D \& Kingdom JC 2005 Bi-potential behavior of cytotrophoblasts in first trimester chorionic villi. Placenta 27 367-374. (doi:10.1016/j.placenta. 2005.03.006) 
Barker DJ 2006 Adult consequences of fetal growth restriction. Clinical Obstetrics and Gynecology 49 270-283. (doi:10.1097/00003081-20060600000009)

Barnea ER, Feldman D, Kaplan M \& Morrish DW 1990 The dual effect of epidermal growth factor upon human chorionic gonadotropin secretion by the first trimester placenta in vitro. Journal of Clinical Endocrinology and Metabolism 71 923-928. (doi:10.1210/jcem-71-4-923)

Bass KE, Morrish D, Roth I, Bhardwaj D, Taylor R, Zhou Y \& Fisher SJ 1994 Human cytotrophoblast invasion is up-regulated by epidermal growth factor: evidence that paracrine factors modify this process. Developmental Biology 164 550-561. (doi:10.1006/dbio.1994.1223)

Beenken A \& Mohammadi M 2009 The FGF family: biology, pathophysiology and therapy. Nature Reviews. Drug Discovery 8 235-253. (doi:10. 1038/nrd2792)

Bhatia S, Faessen GH, Carland G, Balise RL, Gargosky SE, Druzin M, El-Sayed Y, Wilson DM \& Giudice LC 2002 A longitudinal analysis of maternal serum insulin-like growth factor I (IGF-I) and total and nonphosphorylated IGF-binding protein-1 in human pregnancies complicated by intrauterine growth restriction. Journal of Clinical Endocrinology and Metabolism 87 1864-1870. (doi:10.1210/jc.87.4.1864)

Bidwell MC, Eitzman BA, Walmer DK, McLachlan JA \& Gray KD 1995 Analysis of messenger ribonucleic acid and protein for the ligands and receptors of the platelet-derived growth factor signaling pathway in the placenta, extraembryonic membranes, and uterus during the latter half of murine gestation. Endocrinology 136 5189-5201. (doi:10.1210/en. 136.11.5189)

Bloomfield FH, van Zijl PL, Bauer MK \& Harding JE 2002 A chronic low dose infusion of insulin-like growth factor I alters placental function but does not affect fetal growth. Reproduction, Fertility, and Development $\mathbf{1 4}$ 393-400. (doi:10.1071/RD02022)

Casalini P, Iorio MV, Galmozzi E \& Menard S 2004 Role of HER receptors family in development and differentiation. Journal of Cellular Physiology 200 343-350. (doi:10.1002/jcp.20007)

Cellini C, Xu J, Arriaga A \& Buchmiller-Crair TL 2004 Effect of epidermal growth factor infusion on fetal rabbit intrauterine growth retardation and small intestinal development. Journal of Pediatric Surgery 39 891-897 (discussion 891-897). (doi:10.1016/j.jpedsurg.2004.02.008)

Chen WS, Xu PZ, Gottlob K, Chen ML, Sokol K, Shiyanova T, Roninson I, Weng W, Suzuki R, Tobe K et al. 2001 Growth retardation and increased apoptosis in mice with homozygous disruption of the Akt1 gene. Genes and Development 15 2203-2208. (doi:10.1101/gad.913901)

Chong ZZ \& Maiese K 2007 The Src homology 2 domain tyrosine phosphatases SHP-1 and SHP-2: diversified control of cell growth, inflammation, and injury. Histology and Histopathology 22 1251-1267.

Chow SS, Craig ME, Jones CA, Hall B, Catteau J, Lloyd AR \& Rawlinson WD 2008 Differences in amniotic fluid and maternal serum cytokine levels in early midtrimester women without evidence of infection. Cytokine $\mathbf{4 4}$ 78-84. (doi:10.1016/j.cyto.2008.06.009)

Christie GR, Williams DJ, MacIsaac F, Dickinson RJ, Rosewell I \& Keyse SM 2005 The dual-specificity protein phosphatase DUSP9/MKP-4 is essential for placental function but is not required for normal embryonic development. Molecular and Cellular Biology 25 8323-8333. (doi:10.1128/ MCB.25.18.8323-8333.2005)

Cohen S 1962 Isolation of a mouse submaxillary gland protein accelerating incisor eruption and eyelid opening in the new-born animal. Journal of Biological Chemistry 237 1555-1562.

Colvin JS, Bohne BA, Harding GW, McEwen DG \& Ornitz DM 1996 Skeletal overgrowth and deafness in mice lacking fibroblast growth factor receptor 3. Nature Genetics 12 390-397. (doi:10.1038/ng0496-390)

Constancia M, Angiolini E, Sandovici I, Smith P, Smith R, Kelsey G, Dean W, Ferguson-Smith A, Sibley CP, Reik W et al. 2005 Adaptation of nutrient supply to fetal demand in the mouse involves interaction between the Igf2 gene and placental transporter systems. PNAS 102 19219-19224. (doi:10. 1073/pnas.0504468103)

Dackor J, Strunk KE, Wehmeyer MM \& Threadgill DW 2007 Altered trophoblast proliferation is insufficient to account for placental dysfunction in Egfr null embryos. Placenta 28 1211-1218. (doi:10.1016/j.placenta.2007. 07.005)
Dackor J, Caron KM \& Threadgill DW 2009 Placental and embryonic growth restriction in mice with reduced function epidermal growth factor receptor alleles. Genetics 183 207-218. (doi:10.1534/genetics.109.104372)

Daoud G, Amyot M, Rassart E, Masse A, Simoneau L \& Lafond J 2005 ERK1/2 and p38 regulate trophoblasts differentiation in human term placenta. Journal of Physiology 566 409-423. (doi:10.1113/jphysiol. 2005.089326)

Deng CX, Wynshaw-Boris A, Shen MM, Daugherty C, Ornitz DM \& Leder P 1994 Murine FGFR-1 is required for early postimplantation growth and axial organization. Genes and Development 8 3045-3057. (doi:10.1101/gad.8.24.3045)

Dickson MC, Martin JS, Cousins FM, Kulkarni AB, Karlsson S \& Akhurst RJ 1995 Defective haematopoiesis and vasculogenesis in transforming growth factor- $\beta 1$ knock out mice. Development 121 1845-1854.

Efstratiadis A 1998 Genetics of mouse growth. International Journal of Developmental Biology 42 955-976.

Fang J, Furesz TC, Lurent RS, Smith CH \& Fant ME 1997 Spatial polarization of insulin-like growth factor receptors on the human syncytiotrophoblast. Pediatric Research 41 258-265. (doi:10.1203/ 00006450-199702000-00017)

Fang J, Mao D, Smith CH \& Fant ME 2006 IGF regulation of neutral amino acid transport in the BeWo choriocarcinoma cell line (b30 clone): evidence for MAP kinase-dependent and MAP kinase-independent mechanisms. Growth Hormone and IGF Research 16 318-325. (doi:10.1016/j.ghir.2006. 08.002)

Fondacci C, Alsat E, Gabriel R, Blot P, Nessmann C \& Evain-Brion D 1994 Alterations of human placental epidermal growth factor receptor in intrauterine growth retardation. Journal of Clinical Investigation 93 1149-1155. (doi:10.1172/JCI117067)

Forbes K \& Westwood M 2008 The IGF axis and placental function: a mini review. Hormone Research 69 129-137. (doi:10.1159/000112585)

Forbes K, Westwood M, Baker PN \& Aplin JD 2008 Insulin-like growth factor I and II regulate the life cycle of trophoblast in the developing human placenta. American Journal of Physiology. Cell Physiology 294 C1313-C1322. (doi:10.1152/ajpcell.00035.2008)

Forbes K, West G, Garside R, Aplin JD \& Westwood M 2009 The protein-tyrosine phosphatase, SRC homology-2 domain containing protein tyrosine phosphatase-2, is a crucial mediator of exogenous insulin-like growth factor signaling to human trophoblast. Endocrinology 150 4744-4754. (doi:10.1210/en.2009-0166)

Forbes K, Skinner L, Aplin JD \& Westwood M 2010a The tyrosine phosphatase, SHP-1, acts on multiple tyrosine kinase receptors to negatively regulate human cytotrophoblast proliferation. Endocrine Abstracts 21 P316.

Forbes K, Skinner L, Aplin JD \& Westwood M $2010 b$ The tyrosine phosphatase, SHP-1, acts on multiple tyrosine kinase receptors to negatively regulate human cytotrophoblast proliferation. Reproductive Sciences 17 165A.

Forbes K, Souquet B, Garside R, Aplin JD \& Westwood M 2010c Transforming growth factor- $\beta$ (TGF $\beta$ ) receptors I/II differentially regulate TGF $\beta 1$ and IGF-binding protein-3 mitogenic effects in the human placenta. Endocrinology 151 1723-1731. (doi:10.1210/en.2009-0896)

Gambino YP, Maymo JL, Perez-Perez A, Duenas JL, Sanchez-Margalet V, Calvo JC \& Varone CL 2010 17ß-Estradiol enhances leptin expression in human placental cells through genomic and nongenomic actions. Biology of Reproduction 83 42-51. (doi:10.1095/biolreprod.110.083535)

Garcia-Lloret MI, Yui J, Winkler-Lowen B \& Guilbert LJ 1996 Epidermal growth factor inhibits cytokine-induced apoptosis of primary human trophoblasts. Journal of Cellular Physiology 167 324-332. (doi:10.1002/ (SICI) 1097-4652(199605)167:2 <324::AID-JCP17>3.0.CO;2-7)

Gargosky SE, Owens JA, Walton PE, Owens PC, Wallace JC \& Ballard FJ 1991 Administration of insulin-like growth factor-I, but not growth hormone, increases maternal weight gain in late pregnancy without affecting fetal or placental growth. Journal of Endocrinology 130 395-400. (doi:10.1677/joe.0.1300395)

Gassmann M, Casagranda F, Orioli D, Simon H, Lai C, Klein R \& Lemke G 1995 Aberrant neural and cardiac development in mice lacking the ErbB4 neuregulin receptor. Nature 378 390-394. (doi:10.1038/378390a0) 
Giannoukakis N, Deal C, Paquette J, Goodyer CG \& Polychronakos C 1993 Parental genomic imprinting of the human IGF2 gene. Nature Genetics 4 98-101. (doi:10.1038/ng0593-98)

Giudice LC, de Zegher F, Gargosky SE, Dsupin BA, de las Fuentes L, Crystal RA, Hintz RL \& Rosenfeld RG 1995 Insulin-like growth factors and their binding proteins in the term and preterm human fetus and neonate with normal and extremes of intrauterine growth. Journal of Clinical Endocrinology and Metabolism 80 1548-1555. (doi:10.1210/jc.80.5.1548)

Gluckman PD, Morel PC, Ambler GR, Breier BH, Blair HT \& McCutcheon SN 1992 Elevating maternal insulin-like growth factor-I in mice and rats alters the pattern of fetal growth by removing maternal constraint. Journal of Endocrinology 134 R1-R3. (doi:10.1677/joe.0.134R001)

Gohlke BC, Fahnenstich H, Dame C \& Albers N 2004 Longitudinal data for intrauterine levels of fetal IGF-I and IGF-II. Hormone Research 61 200-204. (doi:10.1159/000076552)

Goldman-Wohl D \& Yagel S 2002 Regulation of trophoblast invasion: from normal implantation to pre-eclampsia. Molecular and Cellular Endocrinology 187 233-238. (doi:10.1016/S0303-7207(01)00687-6)

Gow CB, Singleton DJ, Silvapulle MJ \& Moore GP 1991 Lack of effect of epidermal growth factor treatment in late-pregnant ewes on subsequent lactation. Journal of Dairy Research 58 1-11. (doi:10.1017/S002202990 0033458)

Graham CH, Lysiak JJ, McCrae KR \& Lala PK 1992 Localization of transforming growth factor- $\beta$ at the human fetal-maternal interface: role in trophoblast growth and differentiation. Biology of Reproduction 46 561-572. (doi:10.1095/biolreprod46.4.561)

Grissa O, Yessoufou A, Mrisak I, Hichami A, Amoussou-Guenou D, Grissa A, Djrolo F, Moutairou K, Miled A, Khairi H et al. 2010 Growth factor concentrations and their placental mRNA expression are modulated in gestational diabetes mellitus: possible interactions with macrosomia. BMC Pregnancy and Childbirth 10 7. (doi:10.1186/1471-2393-10-7)

Hamilton GS, Lysiak JJ, Han VK \& Lala PK 1998 Autocrine-paracrine regulation of human trophoblast invasiveness by insulin-like growth factor (IGF)-II and IGF-binding protein (IGFBP)-1. Experimental Cell Research 244 147-156. (doi:10.1006/excr.1998.4195)

Han J, Li L, Hu J, Yu L, Zheng Y, Guo J, Zheng X, Yi P \& Zhou Y 2010 Epidermal growth factor stimulates human trophoblast cell migration through Rho A and Rho C activation. Endocrinology 151 1732-1742. (doi:10.1210/en.2009-0845)

Harris RC, Chung E \& Coffey RJ 2003 EGF receptor ligands. Experimental Cell Research 284 2-13. (doi:10.1016/S0014-4827(02)00105-2)

Harris LK, Jones CJ \& Aplin JD 2009 Adhesion molecules in human trophoblast - a review. II. Extravillous trophoblast. Placenta 30 299-304. (doi:10.1016/j.placenta.2008.12.003)

Hatano N, Mori Y, Oh-hora M, Kosugi A, Fujikawa T, Nakai N, Niwa H, Miyazaki J, Hamaoka T \& Ogata M 2003 Essential role for ERK2 mitogenactivated protein kinase in placental development. Genes to Cells 8 847-856. (doi:10.1046/j.1365-2443.2003.00680.x)

Hernandez-Valencia M, Zarate A, Ochoa R, Fonseca ME, Amato D \& De Jesus Ortiz M 2001 Insulin-like growth factor I, epidermal growth factor and transforming growth factor $\beta$ expression and their association with intrauterine fetal growth retardation, such as development during human pregnancy. Diabetes, Obesity and Metabolism 3 457-462. (doi:10.1046/j.1463-1326.2001.00168.x)

Herz J, Clouthier DE \& Hammer RE 1992 LDL receptor-related protein internalizes and degrades uPA-PAI-1 complexes and is essential for embryo implantation. Cell 71 411-421. (doi:10.1016/0092-8674(92)90511-A)

Hill DJ, Tevaarwerk GJ, Caddell C, Arany E, Kilkenny D \& Gregory M 1995 Fibroblast growth factor 2 is elevated in term maternal and cord serum and amniotic fluid in pregnancies complicated by diabetes: relationship to fetal and placental size. Journal of Clinical Endocrinology and Metabolism $\mathbf{8 0}$ 2626-2632. (doi:10.1210/jc.80.9.2626)

Hoch RV \& Soriano P 2003 Roles of PDGF in animal development. Development 130 4769-4784. (doi:10.1242/dev.00721)

Hoffmann P, Saoudi Y, Benharouga M, Graham CH, Schaal JP, Mazouni C, Feige JJ \& Alfaidy N 2009 Role of EG-VEGF in human placentation: physiological and pathological implications. Journal of Cellular and Molecular Medicine 13 2224-2235. (doi:10.1111/j.1582-4934.2008.00554.x)
Holmes R, Montemagno R, Jones J, Preece M, Rodeck C \& Soothill P 1997 Fetal and maternal plasma insulin-like growth factors and binding proteins in pregnancies with appropriate or retarded fetal growth. Early Human Development 49 7-17. (doi:10.1016/S0378-3782(97)01867-7)

Holmes R, Porter H, Newcomb P, Holly JM \& Soothill P 1999 An immunohistochemical study of type I insulin-like growth factor receptors in the placentae of pregnancies with appropriately grown or growth restricted fetuses. Placenta 20 325-330. (doi:10.1053/plac.1998.0387)

Huber A, Hefler L, Tempfer C, Zeisler H, Lebrecht A \& Husslein P 2002 Transforming growth factor- $\beta 1$ serum levels in pregnancy and preeclampsia. Acta Obstetricia et Gynecologica Scandinavica 81 168-171. (doi:10. 1034/j.1600-0412.2002.810214.x)

Hubinette A, Lichtenstein P, Brismar K, Vatten L, Jacobsen G, Ekbom A \& Cnattingius S 2003 Serum insulin-like growth factors in normal pregnancy and in pregnancies complicated by preeclampsia. Acta Obstetricia et Gynecologica Scandinavica 82 1004-1009. (doi:10.1034/j.1600-0412.2003.00034.x)

Humphrey RG, Sonnenberg-Hirche C, Smith SD, Hu C, Barton A, Sadovsky Y \& Nelson DM 2008 Epidermal growth factor abrogates hypoxia-induced apoptosis in cultured human trophoblasts through phosphorylation of BAD Serine 112. Endocrinology 149 2131-2137. (doi:10.1210/en.2007-1253)

Irving JA \& Lala PK 1995 Functional role of cell surface integrins on human trophoblast cell migration: regulation by TGF- $\beta$, IGF-II, and IGFBP-1. Experimental Cell Research 217 419-427. (doi:10.1006/excr.1995.1105)

Irwin JC, Suen LF, Faessen GH, Popovici RM \& Giudice LC 2001 Insulinlike growth factor (IGF)-II inhibition of endometrial stromal cell tissue inhibitor of metalloproteinase- 3 and IGF-binding protein- 1 suggests paracrine interactions at the decidua:trophoblast interface during human implantation. Journal of Clinical Endocrinology and Metabolism 86 2060-2064. (doi:10.1210/jc.86.5.2060)

Jansson T \& Powell TL 2006 Human placental transport in altered fetal growth: does the placenta function as a nutrient sensor? - a review Placenta 27 91-97. (doi:10.1016/j.placenta.2005.11.010)

Jarvenpaa J, Vuoristo JT, Savolainen ER, Ukkola O, Vaskivuo T \& Ryynanen M 2007 Altered expression of angiogenesis-related placental genes in preeclampsia associated with intrauterine growth restriction. Gynecological Endocrinology 23 351-355. (doi:10.1080/09513590701350291)

Javelaud D \& Mauviel A 2005 Crosstalk mechanisms between the mitogenactivated protein kinase pathways and Smad signaling downstream of TGF- $\beta$ : implications for carcinogenesis. Oncogene 24 5742-5750. (doi:10.1038/sj.onc.1208928)

Jiang H, Xun P, Luo G, Wang Q, Cai Y, Zhang Y \& Yu B 2009 Levels of insulin-like growth factors and their receptors in placenta in relation to macrosomia. Asia Pacific Journal of Clinical Nutrition 18 171-178.

Johnstone ED, Mackova M, Das S, Payne SG, Lowen B, Sibley CP, Chan G \& Guilbert LJ 2005a Multiple anti-apoptotic pathways stimulated by EGF in cytotrophoblasts. Placenta 26 548-555. (doi:10.1016/j.placenta.2004.08.012)

Johnstone ED, Sibley CP, Lowen B \& Guilbert LJ 2005b Epidermal growth factor stimulation of trophoblast differentiation requires MAPK11/14 (p38 MAP kinase) activation. Biology of Reproduction 73 1282-1288. (doi:10. 1095/biolreprod.105.044206)

Jokhi PP, King A \& Loke YW 1994 Reciprocal expression of epidermal growth factor receptor (EGF-R) and c-erbB2 by non-invasive and invasive human trophoblast populations. Cytokine 6 433-442. (doi:10.1016/10434666(94)90068-X)

Jones JI \& Clemmons DR 1995 Insulin-like growth factors and their binding proteins: biological actions. Endocrine Reviews 16 3-34. (doi:10.1210/ edrv-16-1-3)

Jones RL, Stoikos C, Findlay JK \& Salamonsen LA 2006 TGF- $\beta$ superfamily expression and actions in the endometrium and placenta. Reproduction $\mathbf{1 3 2}$ 217-232. (doi:10.1530/rep.1.01076)

Kallapur S, Ormsby I \& Doetschman T 1999 Strain dependency of TGF $\beta 1$ function during embryogenesis. Molecular Reproduction and Development 52 341-349. (doi:10.1002/(SICI)1098-2795(199904)52:4<341::AIDMRD2 > 3.0.CO;2-N)

Kamei Y, Tsutsumi O, Yamakawa A, Oka Y, Taketani Y \& Imaki J 1999 Maternal epidermal growth factor deficiency causes fetal hypoglycemia and 
intrauterine growth retardation in mice: possible involvement of placental glucose transporter GLUT3 expression. Endocrinology 140 4236-4243. (doi:10.1210/en.140.9.4236)

Karl PI 1995 Insulin-like growth factor-1 stimulates amino acid uptake by the cultured human placental trophoblast. Journal of Cellular Physiology $\mathbf{1 6 5}$ 83-88. (doi:10.1002/jcp.1041650111)

Karmakar S \& Das C 2002 Regulation of trophoblast invasion by IL-1 $\beta$ and TGF-ß1. American Journal of Reproductive Immunology 48 210-219. (doi:10. 1034/j.1600-0897.2002.01151.x)

Kaufmann P, Black S \& Huppertz B 2003 Endovascular trophoblast invasion: implications for the pathogenesis of intrauterine growth retardation and preeclampsia. Biology of Reproduction 69 1-7. (doi:10.1095/biolreprod.102. 014977)

Kiess W, Kratzsch J, Keller E, Schneider A, Raile K, Klammt J, Seidel B, Garten A, Schmidt H \& Pfäfle R 2005 Clinical examples of disturbed IGF signaling: intrauterine and postnatal growth retardation due to mutations of the insulin-like growth factor I receptor (IGF-IR) gene. Reviews in Endocrine and Metabolic Disorders 6 183-187. (doi:10.1007/ s11154-005-3049-5)

Kingdom J, Huppertz B, Seaward G \& Kaufmann P 2000 Development of the placental villous tree and its consequences for fetal growth. European Journal of Obstetrics, Gynecology, and Reproductive Biology 92 35-43. (doi:10. 1016/S0301-2115(00)00423-1)

Kita N, Mitsushita J, Ohira S, Takagi Y, Ashida T, Kanai M, Nikaido T \& Konishi I 2003 Expression and activation of MAP kinases, ERK1/2, in the human villous trophoblasts. Placenta 24 164-172. (doi:10.1053/plac. 2002.0880)

Klauwer D, Blum WF, Hanitsch S, Rascher W, Lee PD \& Kiess W 1997 IGF-I, IGF-II, free IGF-I and IGFBP-1, -2 and -3 levels in venous cord blood: relationship to birthweight, length and gestational age in healthy newborns. Acta Paediatrica 86 826-833. (doi:10.1111/j.1651-2227.1997. tb08605.x)

Knofler M 2010 Critical growth factors and signalling pathways controlling human trophoblast invasion. International Journal of Developmental Biology $\mathbf{5 4}$ 269-280. (doi:10.1387/ijdb.082769mk)

Knofler M, Simmons DG, Lash GE, Harris LK \& Armant DR 2008 Regulation of trophoblast invasion - a workshop report. Placenta 29 S26-S28. (doi:10.1016/j.placenta.2007.11.008)

Koren S \& Fantus IG 2007 Inhibition of the protein tyrosine phosphatase PTP1B: potential therapy for obesity, insulin resistance and type-2 diabetes mellitus. Best Practice and Research. Clinical Endocrinology and Metabolism 21 621-640. (doi:10.1016/j.beem.2007.08.004)

Kruis T, Klammt J, Galli-Tsinopoulou A, Wallborn T, Schlicke M, Muller E, Kratzsch J, Korner A, Odeh R, Kiess W et al. 2010 Heterozygous mutation within a kinase-conserved motif of the insulin-like growth factor I receptor causes intrauterine and postnatal growth retardation. Journal of Clinical Endocrinology and Metabolism 95 1137-1142. (doi:10.1210/jc.2009-1433)

Lacey H, Haigh T, Westwood M \& Aplin JD 2002 Mesenchymally-derived insulin-like growth factor 1 provides a paracrine stimulus for trophoblast migration. BMC Developmental Biology 2 5. (doi:10.1186/1471-213X-2-5)

LaMarca HL, Dash PR, Vishnuthevan K, Harvey E, Sullivan DE, Morris CA \& Whitley GS 2008 Epidermal growth factor-stimulated extravillous cytotrophoblast motility is mediated by the activation of PI3-K, Akt and both $\mathrm{p} 38$ and $\mathrm{p} 42 / 44$ mitogen-activated protein kinases. Human Reproduction 23 1733-1741. (doi:10.1093/humrep/den178)

Langford K, Nicolaides K \& Miell JP 1998 Maternal and fetal insulin-like growth factors and their binding proteins in the second and third trimesters of human pregnancy. Human Reproduction 13 1389-1393. (doi:10.1093/ humrep/13.5.1389)

Larsen T, Main K, Andersson AM, Juul A, Greisen G \& Skakkebaek NE 1996 Growth hormone, insulin-like growth factor I and its binding proteins 1 and 3 in last trimester intrauterine growth retardation with increased pulsatility index in the umbilical artery. Clinical Endocrinology 45 315-319. (doi:10.1046/j.1365-2265.1996.553812.x)

Larsson J, Goumans M-J, Sjostrand LJ, van Rooijen MA, Ward D, Leveen P, Xu X, ten Dijke P, Mummery CL \& Karlsson S 2001 Abnormal angiogenesis but intact hematopoietic potential in TGF-[ $\beta]$ type I receptor-deficient mice. EMBO Journal 20 1663-1673. (doi:10.1093/ emboj/20.7.1663)

Lau MM, Stewart CE, Liu Z, Bhatt H, Rotwein P \& Stewart CL 1994 Loss of the imprinted IGF2/cation-independent mannose 6-phosphate receptor results in fetal overgrowth and perinatal lethality. Genes and Development 8 2953-2963. (doi:10.1101/gad.8.24.2953)

Laviola L, Perrini S, Belsanti G, Natalicchio A, Montrone C, Leonardini A, Vimercati A, Scioscia M, Selvaggi L, Giorgino R et al. 2005 Intrauterine growth restriction in humans is associated with abnormalities in placental insulin-like growth factor signaling. Endocrinology 146 1498-1505. (doi:10. 1210/en.2004-1332)

Lee KF, Simon H, Chen H, Bates B, Hung MC \& Hauser C 1995 Requirement for neuregulin receptor erbB2 in neural and cardiac development. Nature 378 394-398. (doi:10.1038/378394a0)

Le Roith D, Bondy C, Yakar S, Liu J-L \& Butler A 2001 The somatomedin hypothesis: 2001. Endocrine Reviews 22 53-74. (doi:10.1210/er.22.1.53)

Letterio JJ, Geiser AG, Kulkarni AB, Roche NS, Sporn MB \& Roberts AB 1994 Maternal rescue of transforming growth factor- $\beta 1$ null mice. Science 264 1936-1938. (doi:10.1126/science.8009224)

Leveen P, Pekny M, Gebre-Medhin S, Swolin B, Larsson E \& Betsholtz C 1994 Mice deficient for PDGF B show renal, cardiovascular, and hematological abnormalities. Genes and Development 8 1875-1887. (doi:10. 1101/gad.8.16.1875)

Levine AJ, Feng Z, Mak TW, You H \& Jin S 2006 Coordination and communication between the $\mathrm{p} 53$ and IGF-1-AKT-TOR signal transduction pathways. Genes and Development 20 267-275. (doi:10.1101/gad. 1363206)

Li RH \& Zhuang LZ 1997 The effects of growth factors on human normal placental cytotrophoblast cell proliferation. Human Reproduction $\mathbf{1 2}$ 830-834. (doi:10.1093/humrep/12.4.830)

Liu JP, Baker J, Perkins AS, Robertson EJ \& Efstratiadis A 1993 Mice carrying null mutations of the genes encoding insulin-like growth factor I (Igf-1) and type 1 IGF receptor (Igf1r). Cell 75 59-72. (doi:10.1016/ S0092-8674(05)80084-4)

Looman C, Sun T, Yu Y, Zieba A, Ahgren A, Feinstein R, Forsberg H, Hellberg C, Heldin CH, Zhang XQ et al. 2007 An activating mutation in the PDGF receptor- $\beta$ causes abnormal morphology in the mouse placenta. International Journal of Developmental Biology 51 361-370. (doi:10.1387/ijdb. 072301cl)

Ludwig T, Eggenschwiler J, Fisher P, D’Ercole AJ, Davenport ML \& Efstratiadis A 1996 Mouse mutants lacking the type 2 IGF receptor (IGF2R) are rescued from perinatal lethality in Igf2 and Igf1r null backgrounds. Developmental Biology 177 517-535. (doi:10.1006/dbio. 1996.0182)

Luetteke NC, Qiu TH, Fenton SE, Troyer KL, Riedel RF, Chang A \& Lee DC 1999 Targeted inactivation of the EGF and amphiregulin genes reveals distinct roles for EGF receptor ligands in mouse mammary gland development. Development 126 2739-2750.

Lyall F 2006 Mechanisms regulating cytotrophoblast invasion in normal pregnancy and pre-eclampsia. Australian and New Zealand Journal of Obstetrics and Gynaecology 46 266-273. (doi:10.1111/j.1479-828X.2006.00589.x)

Magarinos MP, Sanchez-Margalet V, Kotler M, Calvo JC \& Varone CL 2007 Leptin promotes cell proliferation and survival of trophoblastic cells. Biology of Reproduction 76 203-210. (doi:10.1095/biolreprod.106.051391)

Malamitsi-Puchner A, Briana DD, Gourgiotis D, Boutsikou M, Puchner KP, Baka S, Marmarinos A \& Hassiakos D 2007 Insulin-like growth factor (IGF)-I and insulin in normal and growth-restricted mother/infant pairs. Mediators of Inflammation 2007 42646. (doi:10.1155/2007/42646)

Mariano JM, Montuenga LM, Prentice MA, Cuttitta F \& Jakowlew SB 1998 Concurrent and distinct transcription and translation of transforming growth factor- $\beta$ type I and type II receptors in rodent embryogenesis. International Journal of Developmental Biology 42 1125-1136.

Maruo T \& Mochizuki M 1987 Immunohistochemical localization of epidermal growth factor receptor and myc oncogene product in human placenta: implication for trophoblast proliferation and differentiation. American Journal of Obstetrics and Gynecology 156 721-727. 
Maruo T, Matsuo H, Oishi T, Hayashi M, Nishino R \& Mochizuki M 1987 Induction of differentiated trophoblast function by epidermal growth factor: relation of immunohistochemically detected cellular epidermal growth factor receptor levels. Journal of Clinical Endocrinology and Metabolism 64 744-750. (doi:10.1210/jcem-64-4-744)

McIntyre HD, Serek R, Crane DI, Veveris-Lowe T, Parry A, Johnson S, Leung KC, Ho KK, Bougoussa M, Hennen G et al. 2000 Placental growth hormone (GH), GH-binding protein, and insulin-like growth factor axis in normal, growth-retarded, and diabetic pregnancies: correlations with fetal growth. Journal of Clinical Endocrinology and Metabolism 85 1143-1150. (doi:10.1210/jc.85.3.1143)

McKinnon T, Chakraborty C, Gleeson LM, Chidiac P \& Lala PK 2001 Stimulation of human extravillous trophoblast migration by IGF-II is mediated by IGF type 2 receptor involving inhibitory $\mathrm{G}$ protein(s) and phosphorylation of MAPK. Journal of Clinical Endocrinology and Metabolism 86 3665-3674. (doi:10.1210/jc.86.8.3665)

Miettinen PJ, Berger JE, Meneses J, Phung Y, Pedersen RA, Werb Z \& Derynck R 1995 Epithelial immaturity and multiorgan failure in mice lacking epidermal growth factor receptor. Nature 376 337-341. (doi:10. 1038/376337a0)

Moll SJ, Jones CJ, Crocker IP, Baker PN \& Heazell AE 2007 Epidermal growth factor rescues trophoblast apoptosis induced by reactive oxygen species. Apoptosis 12 1611-1622. (doi:10.1007/s10495-007-0092-6)

Morison IM, Becroft DM, Taniguchi T, Woods CG \& Reeve AE 1996 Somatic overgrowth associated with overexpression of insulin-like growth factor II. Nature Medicine 2 311-316. (doi:10.1038/nm0396-311)

Morita H, Mizutori M, Takeuchi K, Motoyama S \& Maruo T 2001 Abundant expression of platelet-derived growth factor in spiral arteries in decidua associated with pregnancy-induced hypertension and its relevance to atherosis. European Journal of Endocrinology 144 271-276. (doi:10.1530/ eje.0.1440271)

Morrish DW, Bhardwaj D \& Paras MT 1991 Transforming growth factor $\beta 1$ inhibits placental differentiation and human chorionic gonadotropin and human placental lactogen secretion. Endocrinology 129 22-26. (doi:10. 1210/endo-129-1-22)

Mudgett JS, Ding J, Guh-Siesel L, Chartrain NA, Yang L, Gopal S \& Shen MM 2000 Essential role for $\mathrm{p} 38 \alpha$ mitogen-activated protein kinase in placental angiogenesis. PNAS 97 10454-10459. (doi:10.1073/pnas. 180316397)

Muenke M \& Schell U 1995 Fibroblast-growth-factor receptor mutations in human skeletal disorders. Trends in Genetics 11 308-313. (doi:10.1016/ S0168-9525(00)89088-5)

Murayama Y, Okamoto T, Ogata E, Asano T, Iiri T, Katada T, Ui M, Grubb JH, Sly WS \& Nishimoto I 1990 Distinctive regulation of the functional linkage between the human cation-independent mannose 6-phosphate receptor and GTP-binding proteins by insulin-like growth factor II and mannose 6-phosphate. Journal of Biological Chemistry 265 17456-17462.

Natanson-Yaron S, Anteby EY, Greenfield C, Goldman-Wohl D, Hamani Y, Hochner-Celnikier D \& Yagel S 2007 FGF10 and sprouty 2 modulate trophoblast invasion and branching morphogenesis. Molecular Human Reproduction 13 511-519. (doi:10.1093/molehr/gam034)

Neel BG \& Tonks NK 1997 Protein tyrosine phosphatases in signal transduction. Current Opinion in Cell Biology 9 193-204. (doi:10.1016/ S0955-0674(97)80063-4)

Neel BG, Gu H \& Pao L 2003 The 'Shp'ing news: SH2 domain-containing tyrosine phosphatases in cell signaling. Trends in Biochemical Sciences $\mathbf{2 8}$ 284-293. (doi:10.1016/S0968-0004(03)00091-4)

Netchine I, Azzi S, Houang M, Seurin D, Perin L, Ricort JM, Daubas C, Legay C, Mester J, Herich R et al. 2009 Partial primary deficiency of insulin-like growth factor (IGF)-I activity associated with IGF1 mutation demonstrates its critical role in growth and brain development. Journal of Clinical Endocrinology and Metabolism 94 3913-3921. (doi:10.1210/jc.20090452)

Normanno N, De Luca A, Bianco C, Strizzi L, Mancino M, Maiello MR, Carotenuto A, De Feo G, Caponigro F \& Salomon DS 2006 Epidermal growth factor receptor (EGFR) signaling in cancer. Gene 366 2-16. (doi:10.1016/j.gene.2005.10.018)
Norris K, Norris F, Kono DH, Vestergaard H, Pedersen O, Theofilopoulos AN \& Moller NP 1997 Expression of protein-tyrosine phosphatases in the major insulin target tissues. FEBS Letters 415 243-248. (doi:10.1016/ S0014-5793(97)01133-2)

Ohlsson R, Falck P, Hellstrom M, Lindahl P, Bostrom H, Franklin G, Ahrlund-Richter L, Pollard J, Soriano P \& Betsholtz C 1999 PDGFB regulates the development of the labyrinthine layer of the mouse fetal placenta. Developmental Biology 212 124-136. (doi:10.1006/ dbio.1999.9306)

Olausson H, Lof M, Brismar K, Forsum E \& Sohlstrom A 2010 Maternal serum concentrations of insulin-like growth factor (IGF)-I and IGF binding protein-1 before and during pregnancy in relation to maternal body weight and composition and infant birth weight. British Journal of Nutrition 11 1-7. (doi:10.1017/S0007114510001224)

Ong K, Kratzsch J, Kiess W, Costello M, Scott C \& Dunger D 2000 Size at birth and cord blood levels of insulin, insulin-like growth factor I (IGF-I), IGF-II, IGF-binding protein-1 (IGFBP-1), IGFBP-3, and the soluble IGF-II/mannose-6-phosphate receptor in term human infants. The ALSPAC Study Team. Avon Longitudinal Study of Pregnancy and Childhood. Journal of Clinical Endocrinology and Metabolism 85 4266-4269. (doi:10.1210/jc.85.11.4266)

Ortega S, Ittmann M, Tsang SH, Ehrlich M \& Basilico C 1998 Neuronal defects and delayed wound healing in mice lacking fibroblast growth factor 2. PNAS 95 5672-5677. (doi:10.1073/pnas.95.10.5672)

Oshima M, Oshima H \& Taketo MM 1996 TGF-[ $\beta]$ receptor type II deficiency results in defects of yolk sac hematopoiesis and vasculogenesis. Developmental Biology 179 297-302. (doi:10.1006/dbio.1996.0259)

Osorio M, Torres J, Moya F, Pezzullo J, Salafia C, Baxter R, Schwander J \& Fant M 1996 Insulin-like growth factors (IGFs) and IGF binding proteins-1, -2 , and -3 in newborn serum: relationships to fetoplacental growth at term. Early Human Development 46 15-26. (doi:10.1016/03783782(96)01737-9)

Ostlund E, Tally M \& Fried G 2002 Transforming growth factor-beta1 in fetal serum correlates with insulin-like growth factor-I and fetal growth. Obstetrics \& Gynecology 100 567-573. (doi:10.1016/S0029-7844(02) 02173-7)

Pearson G, Robinson F, Beers Gibson T, Xu BE, Karandikar M, Berman K \& Cobb MH 2001 Mitogen-activated protein (MAP) kinase pathways: regulation and physiological functions. Endocrine Reviews 22 153-183. (doi:10.1210/er.22.2.153)

Pijnenborg R, Vercruysse L \& Hanssens M 2006 The uterine spiral arteries in human pregnancy: facts and controversies. Placenta 27 939-958. (doi:10. 1016/j.placenta.2005.12.006)

Population, Censuses \& Surveys Office 2007 Birth statistics: review of the Registrar General on births and patterns of family building in England and Wales. In Series FM1. London: H.M.S.O.

Power LL, Popplewell EJ, Holloway JA, Diaper ND, Warner JO \& Jones CA 2002 Immunoregulatory molecules during pregnancy and at birth. Journal of Reproductive Immunology 56 19-28. (doi:10.1016/S0165-0378 (01)00146-2)

Prenzel N, Fischer OM, Streit S, Hart S \& Ullrich A 2001 The epidermal growth factor receptor family as a central element for cellular signal transduction and diversification. Endocrine-Related Cancer 8 11-31. (doi:10. 1677/erc.0.0080011)

Qian D, Lin HY, Wang HM, Zhang X, Liu DL, Li QL \& Zhu C 2004 Involvement of ERK1/2 pathway in TGF- $\beta 1$-induced VEGF secretion in normal human cytotrophoblast cells. Molecular Reproduction and Development 68 198-204. (doi:10.1002/mrd.20061)

Rappolee DA, Yogesh P \& Kristine J 1998 Expression of fibroblast growth factor receptors in peri-implantation mouse embryos. Molecular Reproduction and Development 51 254-264. (doi:10.1002/(SICI)1098-2795(199811) 51:3<254::AID-MRD4>3.0.CO;2-O)

Reece EA, Wiznitzer A, Le E, Homko CJ, Behrman H \& Spencer EM 1994 The relation between human fetal growth and fetal blood levels of insulinlike growth factors I and II, their binding proteins, and receptors. Obstetrics and Gynecology 84 88-95. 
Renaud SJ, Sullivan R \& Graham CH 2009 Tumour necrosis factor $\alpha$ stimulates the production of monocyte chemoattractants by extravillous trophoblast cells via differential activation of MAPK pathways. Placenta 30 313-319. (doi:10.1016/j.placenta.2009.01.001)

Richard CA, Jones JM \& DeLoia JA 2008 Comparison of cell cycle regulatory gene mRNA in three different types of human trophoblasts and effect of transforming growth factor. Journal of Obstetrics and Gynaecology Research 34 152-161. (doi:10.1111/j.1447-0756.2008.00753.x)

Riethmacher D, Sonnenberg-Riethmacher E, Brinkmann V, Yamaai T, Lewin GR \& Birchmeier C 1997 Severe neuropathies in mice with targeted mutations in the ErbB3 receptor. Nature 389 725-730. (doi:10.1038/39593)

Rojas A, Padidam M, Cress D \& Grady WM 2009 TGF- $\beta$ receptor levels regulate the specificity of signaling pathway activation and biological effects of TGF- $\beta$. Biochimica et Biophysica Acta 1793 1165-1173. (doi:10.1016/ j.bbamcr.2009.02.001)

Roos S, Lagerlof O, Wennergren M, Powell TL \& Jansson T 2009 Regulation of amino acid transporters by glucose and growth factors in cultured primary human trophoblast cells is mediated by mTOR signaling. American Journal of Physiology. Cell Physiology 297 C723-C731. (doi:10.1152/ajpcell.00191.2009)

Roth S, Abernathy MP, Lee WH, Pratt L, Denne S, Golichowski A \& Pescovitz OH 1996 Insulin-like growth factors I and II peptide and messenger RNA levels in macrosomic infants of diabetic pregnancies. Journal of the Society for Gynecologic Investigation 3 78-84. (doi:10.1016/10715576(95)00048-8)

Saba-El-Leil MK, Vella FD, Vernay B, Voisin L, Chen L, Labrecque N, Ang SL \& Meloche S 2003 An essential function of the mitogenactivated protein kinase Erk2 in mouse trophoblast development. EMBO Reports 4 964-968. (doi:10.1038/sj.embor.embor939)

Saxton TM, Henkemeyer M, Gasca S, Shen R, Rossi DJ, Shalaby F, Feng GS \& Pawson T 1997 Abnormal mesoderm patterning in mouse embryos mutant for the SH2 tyrosine phosphatase Shp-2. EMBO Journal 16 2352-2364. (doi:10.1093/emboj/16.9.2352)

Scifres CM \& Nelson DM 2009 Intrauterine growth restriction, human placental development and trophoblast cell death. Journal of Physiology $\mathbf{5 8 7}$ 3453-3458. (doi:10.1113/jphysiol.2009.173252)

Scott J, Urdea M, Quiroga M, Sanchez-Pescador R, Fong N, Selby M, Rutter WJ \& Bell GI 1983 Structure of a mouse submaxillary messenger RNA encoding epidermal growth factor and seven related proteins. Science 221 236-240. (doi:10.1126/science.6602382)

Selesniemi K, Reedy M, Gultice A, Guilbert LJ \& Brown TL 2005 Transforming growth factor- $\beta$ induces differentiation of the labyrinthine trophoblast stem cell line SM10. Stem Cells and Development 14 697-711. (doi:10.1089/scd.2005.14.697)

Senior PV, Byrne S, Brammar WJ \& Beck F 1990 Expression of the IGF-II/mannose-6-phosphate receptor mRNA and protein in the developing rat. Development 109 67-73.

Seo DW, Kim SH, Eom SH, Yoon HJ, Cho YR, Kim PH, Kim YK, Han JW, Diaz T, Wei BY et al. 2008 TIMP-2 disrupts FGF-2-induced downstream signaling pathways. Microvascular Research 76 145-151. (doi:10.1016/j.mvr. 2008.07.003)

Sferruzzi-Perri AN, Owens JA, Pringle KG, Robinson JS \& Roberts CT 2006 Maternal insulin-like growth factors-I and -II act via different pathways to promote fetal growth. Endocrinology 147 3344-3355. (doi:10. 1210/en.2005-1328)

Sferruzzi-Perri AN, Owens JA, Standen P, Taylor RL, Robinson JS \& Roberts CT 2007 Early pregnancy maternal endocrine insulin-like growth factor I programs the placenta for increased functional capacity throughout gestation. Endocrinology 148 4362-4370. (doi:10.1210/en.2007-0411)

Sferruzzi-Perri AN, Owens JA, Standen P \& Roberts CT 2008 Maternal insulin-like growth factor-II promotes placental functional development via the type 2 IGF receptor in the guinea pig. Placenta 29 347-355. (doi:10. 1016/j.placenta.2008.01.009)

Shigeta K, Hiramatsu Y, Eguchi K \& Sekiba K 1992 Urinary and plasma epidermal growth factor levels are decreased in neonates with intrauterine growth retardation and in their mothers. Biology of the Neonate 62 76-82. (doi:10.1159/000243857)
Shultz LD, Schweitzer PA, Rajan TV, Yi T, Ihle JN, Matthews RJ, Thomas ML \& Beier DR 1993 Mutations at the murine motheaten locus are within the hematopoietic cell protein-tyrosine phosphatase $(\mathrm{Hcph})$ gene. Cell $\mathbf{7 3}$ 1445-1454. (doi:10.1016/0092-8674(93)90369-2)

Sibilia M \& Wagner EF 1995 Strain-dependent epithelial defects in mice lacking the EGF receptor. Science 269 234-238. (doi:10.1126/science.7618085)

Sibley CP, Coan PM, Ferguson-Smith AC, Dean W, Hughes J, Smith P, Reik W, Burton GJ, Fowden AL \& Constancia M 2004 Placental-specific insulin-like growth factor 2 (Igf2) regulates the diffusional exchange characteristics of the mouse placenta. PNAS 101 8204-8208. (doi:10.1073/ pnas.0402508101)

Sohlstrom A, Fernberg P, Owens JA \& Owens PC 2001 Maternal nutrition affects the ability of treatment with IGF-I and IGF-II to increase growth of the placenta and fetus, in guinea pigs. Growth Hormone and IGF Research $\mathbf{1 1}$ 392-398. (doi:10.1054/ghir.2001.0253)

Song Y, Keelan J \& France JT 1996 Activin-A stimulates, while transforming growth factor $\beta 1$ inhibits, chorionic gonadotrophin production and aromatase activity in cultured human placental trophoblasts. Placenta 17 603-610. (doi:10.1016/S0143-4004(96)80078-6)

Soriano P 1994 Abnormal kidney development and hematological disorders in PDGF $\beta$-receptor mutant mice. Genes and Development 8 1888-1896. (doi:10.1101/gad.8.16.1888)

Soriano P 1997 The PDGF $\alpha$ receptor is required for neural crest cell development and for normal patterning of the somites. Development 124 2691-2700.

Stenzinger A, Marker D, Koch P, Hoffmann J, Baal N, Steger K \& Wimmer M 2008 Protein tyrosine phosphatase interacting protein 51 (PTPIP51), mRNA expression and localization of PTPIP51 and its in vitro interacting partner protein tyrosine phosphatase 1B (PTP1B) in human placenta of first, second, and third trimester. Journal of Histochemistry and Cytochemistry 57 143-153. (doi:10.1369/jhc.2008.951533)

Tanaka S, Kunath T, Hadjantonakis AK, Nagy A \& Rossant J 1998 Promotion of trophoblast stem cell proliferation by FGF4. Science 282 2072-2075. (doi:10.1126/science.282.5396.2072)

Tanimura K, Nakago S, Murakoshi H, Takekida S, Moriyama T, Matsuo H, Hashimoto K \& Maruo T 2004 Changes in the expression and cytological localization of $\beta$-cellulin and its receptors (ErbB-1 and ErbB-4) in the trophoblasts in human placenta over the course of pregnancy. European Journal of Endocrinology 151 93-101. (doi:10.1530/eje.0.1510093)

Teesalu T, Blasi F \& Talarico D 1998 Expression and function of the urokinase type plasminogen activator during mouse hemochorial placental development. Developmental Dynamics 213 27-38. (doi:10.1002/ (SICI)1097-0177(199809)213:1 < 27::AID-AJA3 > 3.0.CO;2-)

Tenev T, Keilhack H, Tomic S, Stoyanov B, Stein-Gerlach M, Lammers R, Krivtsov AV, Ullrich A \& Bohmer FD 1997 Both SH2 domains are involved in interaction of SHP-1 with the epidermal growth factor receptor but cannot confer receptor-directed activity to SHP-1/SHP-2 chimera. Journal of Biological Chemistry 272 5966-5973. (doi:10.1074/jbc.272.9.5966)

Tonks NK, Diltz CD \& Fischer EH 1988 Purification of the major proteintyrosine-phosphatases of human placenta. Journal of Biological Chemistry 263 6722-6730.

Tsui HW, Siminovitch KA, de Souza L \& Tsui FW 1993 Motheaten and viable motheaten mice have mutations in the haematopoietic cell phosphatase gene. Nature Genetics 4 124-129. (doi:10.1038/ng0693-124)

Tuncer ZS, Vegh GL, Fulop V, Genest DR, Mok SC \& Berkowitz RS 2000 Expression of epidermal growth factor receptor-related family products in gestational trophoblastic diseases and normal placenta and its relationship with development of postmolar tumor. Gynecologic Oncology 77 389-393. (doi:10.1006/gyno.2000.5777)

Vargas A, Moreau J, Le Bellego F, Lafond J \& Barbeau B 2008 Induction of trophoblast cell fusion by a protein tyrosine phosphatase inhibitor. Placenta 29 170-174. (doi:10.1016/j.placenta.2007.10.012)

Verkauskiene R, Beltrand J, Claris O, Chevenne D, Deghmoun S, Dorgeret S, Alison M, Gaucherand P, Sibony O \& Levy-Marchal C 2007 Impact of fetal growth restriction on body composition and hormonal status at birth in infants of small and appropriate weight for gestational age. European Journal of Endocrinology 157 605-612. (doi:10.1530/EJE-07-0286) 
Vincent AM \& Feldman EL 2002 Control of cell survival by IGF signaling pathways. Growth Hormone and IGF Research 12 193-197. (doi:10.1016/ S1096-6374(02)00017-5)

Vuorela P, Sarkola T, Alfthan H \& Halmesmaki E 2002 Hepatocyte growth factor, epidermal growth factor, and placenta growth factor concentrations in peripheral blood of pregnant women with alcohol abuse. Alcoholism, Clinical and Experimental Research 26 682-687. (doi:10.1111/j.1530-0277. 2002.tb02591.x)

Walenkamp MJ, van der Kamp HJ, Pereira AM, Kant SG, van Duyvenvoorde HA, Kruithof MF, Breuning MH, Romijn JA, Karperien M \& Wit JM 2006 A variable degree of intrauterine and postnatal growth retardation in a family with a missense mutation in the insulin-like growth factor I receptor. Journal of Clinical Endocrinology and Metabolism 91 3062-3070. (doi:10.1210/ jc.2005-1597)

Wallborn T, Wuller S, Klammt J, Kruis T, Kratzsch J, Schmidt G, Schlicke M, Muller E, Schmitz van de Leur H, Kiess W et al. 2010 A heterozygous mutation of the insulin-like growth factor-I receptor causes retention of the nascent protein in the endoplasmic reticulum and results in intrauterine and postnatal growth retardation. Journal of Clinical Endocrinology and Metabolism 95 2316-2324. (doi:10.1210/jc.2009-2404)

Wallner W, Sengenberger R, Strick R, Strissel PL, Meurer B, Beckmann MW \& Schlembach D 2007 Angiogenic growth factors in maternal and fetal serum in pregnancies complicated by intrauterine growth restriction. Clinical Science 112 51-57. (doi:10.1042/CS20060161)

Wang K, Jiang YZ, Chen DB \& Zheng J 2009 Hypoxia enhances FGF2- and VEGF-stimulated human placental artery endothelial cell proliferation: roles of MEK1/2/ERK1/2 and PI3K/AKT1 pathways. Placenta 30 1045-1051. (doi:10.1016/j.placenta.2009.10.007)

Ward A 1997 Beck-Wiedemann syndrome and Wilms' tumour. Molecular Human Reproduction 3 157-168. (doi:10.1093/molehr/3.2.157)

Weinstein M, Xu X, Ohyama K \& Deng CX 1998 FGFR-3 and FGFR-4 function cooperatively to direct alveogenesis in the murine lung. Development 125 3615-3623.

Wen HY, Abbasi S, Kellems RE \& Xia Y 2005 mTOR: a placental growth signaling sensor. Placenta 26 (Supplement A) S63-S69. (doi:10.1016/ j.placenta.2005.02.004)

Wilson DM, Bennett A, Adamson GD, Nagashima RJ, Liu F, DeNatale ML, Hintz RL \& Rosenfeld RG 1982 Somatomedins in pregnancy: a crosssectional study of insulin-like growth factors I and II and somatomedin peptide content in normal human pregnancies. Journal of Clinical Endocrinology and Metabolism 55 858-861. (doi:10.1210/jcem-55-5-858)

Wiznitzer A, Reece EA, Homko C, Furman B, Mazor M \& Levy J 1998 Insulin-like growth factors, their binding proteins, and fetal macrosomia in offspring of nondiabetic pregnant women. American Journal of Perinatology 15 23-28. (doi:10.1055/s-2007-993893)

Woodall SM, Breier BH, Johnston BM, Bassett NS, Barnard R \& Gluckman PD 1999 Administration of growth hormone or IGF-I to pregnant rats on a reduced diet throughout pregnancy does not prevent fetal intrauterine growth retardation and elevated blood pressure in adult offspring. Journal of Endocrinology 163 69-77. (doi:10.1677/joe.0.1630069)
Woods KA \& Savage MO 1996 Laron syndrome: typical and a typical forms. Baillière's Clinical Endocrinology and Metabolism 10 371-387. (doi:10.1016/ S0950-351X(96)80500-3)

Wrighton KH, Lin X \& Feng X-H 2009 Phospho-control of TGF-[ $\beta]$ superfamily signaling. Cell Research 19 8-20. (doi:10.1038/cr.2008.327)

Wylie AA, Pulford DJ, McVie-Wylie AJ, Waterland RA, Evans HK, Chen YT, Nolan CM, Orton TC \& Jirtle RL 2003 Tissue-specific inactivation of murine M6P/IGF2R. American Journal of Pathology 162 321-328.

Xuan YH, Choi YL, Shin YK, Ahn GH, Kim KH, Kim WJ, Lee HC \& Kim SH 2007 Expression of TGF- $\beta$ signaling proteins in normal placenta and gestational trophoblastic disease. Histology and Histopathology 22 227-234.

Yamaguchi TP \& Rossant J 1995 Fibroblast growth factors in mammalian development. Current Opinion in Genetics and Development 5 485-491. (doi:10.1016/0959-437X(95)90053-J)

Yang ZZ, Tschopp O, Hemmings-Mieszczak M, Feng J, Brodbeck D, Perentes E \& Hemmings BA 2003 Protein kinase B $\alpha /$ Akt1 regulates placental development and fetal growth. Journal of Biological Chemistry 278 32124-32131. (doi:10.1074/jbc.M302847200)

Yang W, Klaman LD, Chen B, Araki T, Harada H, Thomas SM, George EL \& Neel BG 2006 An Shp2/SFK/Ras/Erk signaling pathway controls trophoblast stem cell survival. Developmental Cell 10 317-327. (doi:10. 1016/j.devcel.2006.01.002)

Yu Z, Su L, Hoglinger O, Jaramillo ML, Banville D \& Shen S-H 1998 SHP-1 associates with both platelet-derived growth factor receptor and the $\mathrm{p} 85$ subunit of phosphatidylinositol 3-kinase. Journal of Biological Chemistry $\mathbf{2 7 3}$ 3687-3694. (doi:10.1074/jbc.273.6.3687)

Yung HW, Calabrese S, Hynx D, Hemmings BA, Cetin I, Charnock-Jones DS \& Burton GJ 2008 Evidence of placental translation inhibition and endoplasmic reticulum stress in the etiology of human intrauterine growth restriction. American Journal of Pathology 173 451-462. (doi:10.2353/ajpath. 2008.071193)

Zatelli MC, Piccin D, Tagliati F, Bottoni A, Luchin A \& degli Uberti EC 2005 SRC homology-2-containing protein tyrosine phosphatase-1 restrains cell proliferation in human medullary thyroid carcinoma. Endocrinology 146 2692-2698. (doi:10.1210/en.2005-0001)

Zhang YE 2009 Non-Smad pathways in TGF- $\beta$ signaling. Cell Research 19 128-139. (doi:10.1038/cr.2008.328)

Zygmunt M, McKinnon T, Herr F, Lala PK \& Han VK 2005 HCG increases trophoblast migration in vitro via the insulin-like growth factor-II/mannose-6 phosphate receptor. Molecular Human Reproduction 11 261-267. (doi:10.1093/molehr/gah160)

Received in final form 14 July 2010

Accepted 15 July 2010

Made available online as an Accepted Preprint 15 July 2010 